\title{
Heterogeneity of Microglial Activation in the Innate Immune Response in the Brain
}

\author{
Carol A. Colton
}

Received: 4 May 2009 / Accepted: 30 June 2009/Published online: 5 August 2009

(C) The Author(s) 2009. This article is published with open access at Springerlink.com

\begin{abstract}
The immune response in the brain has been widely investigated and while many studies have focused on the proinflammatory cytotoxic response, the brain's innate immune system demonstrates significant heterogeneity. Microglia, like other tissue macrophages, participate in repair and resolution processes after infection or injury to restore normal tissue homeostasis. This review examines the mechanisms that lead to reduction of self-toxicity and to repair and restructuring of the damaged extracellular matrix in the brain. Part of the resolution process involves switching macrophage functional activation to include reduction of proinflammatory mediators, increased production and release of antiinflammatory cytokines, and production of cytoactive factors involved in repair and reconstruction of the damaged brain. Two partially overlapping and complimentary functional macrophage states have been identified and are called alternative activation and acquired deactivation. The immunosuppressive and repair processes of each of these states and how alternative activation and acquired deactivation participate in chronic neuroinflammation in the brain are discussed.
\end{abstract}

Keywords neuroinflammation $\cdot$ microglia .

alternative activation $\cdot$ acquired deactivation .

brain repair · immunosuppression · Alzheimer's disease

\section{Introduction}

The innate immune response in the brain has been extensively studied for a number of years and its unique responses to

C. A. Colton $(\bowtie)$

Division of Neurology, Duke University Medical Center,

Durham 27710 NC, USA

e-mail: Carol.Colton@duke.edu injury and infection have been well described. Many of the published studies have focused on the ability of activated microglia, the brain-specific tissue macrophage, to initiate bystander injury by producing and releasing multiple cytoactive factors. Since the brain is known to have limited neuroregenerative potential, the loss of postmitotic neurons through immune-mediated toxicity can have wide impact throughout the body. In the past 10 years, studies on macrophage function in peripheral tissues such as the lung and liver have led the way to a renewed appreciation of macrophage functional heterogeneity. After the initial "toxic" phase of an innate immune response, immune-activated macrophages orchestrate repair, reconstruction, and resolution of tissue injury. This review will discuss the functional phenotypes that underlie these equally important aspects of macrophage function and the application of these concepts to central nervous system (CNS) injury and recovery after injury. The role of macrophage functional heterogeneity in chronic inflammation of the brain, and in particular Alzheimer's disease (AD) will also be discussed.

\section{Initiation of a tissue immune response}

The body initiates an innate immune response when it sustains nonsterile damage through exposure to toxins or pathogens or sterile damage such as mechanical injury, radiation, or autoimmunity. This response to injury is inherent, preprogrammed, and characteristic of specific immune cells within particular tissues. In the brain, the primary cells in the innate immune response are microglia, although astrocytes and neurons may also play an immune role (Streit and Kincaid-Colton 1995). Like macrophages elsewhere in the body, microglia recognize pathogens via pattern recognition receptors (PRRs) that include specific 
toll-like receptors (TLRs), nucleotide-binding oligomerization domain (NOD) proteins, and non-TLR receptors (e.g., C-type lectin receptors). These membrane and cytosolic receptors interact with classes of pathogen-associated molecular patterns (PAMPs) or with damage-associated molecular patterns (DAMPs) in the environment to initiate cellular defense mechanisms (Han and Ulevitch 2005; Rubartelli and Lotze 2007; Serhan and Levy 2003; Sterka and Marriott 2006). Downstream signaling events begin with engagement of adaptor proteins (e.g., MyD88, Trif, TRADD/TRAF) with surface pathogen receptors. Receptorassociated kinases are recruited to the complex and, in turn, activate a series of additional kinases that phosphorylate transcription factors. The subsequent induction of genes triggers a proinflammatory phase of macrophage activation that typically results in the expression of tumor necrosis factor alpha (TNF- $\alpha$ ), interleukin (IL)-1 $\beta$, and IL-12 proteins as well as chemokines, proteases, and redox proteins that help defend the tissue. Rapid reinforcement of the initial response by the action of released cytoactive factors from both the macrophage itself and the surrounding cells leads to classical activation. This important macrophage state is characterized by involvement of interferon gamma (IFN- $\gamma$ ), a cytokine that coordinates induction signals by initiation of the "killing" phase of macrophage function (Adams and Hamilton 1987). Well known in the periphery as a product of $\mathrm{T}$ cells, IFN- $\gamma$ is most likely produced by microglia (and astrocytes) on immune stimulation with PAMPs (Suzuki et al. 2005) and is also a critical component of the brain's innate immune response.

The tissue defense mechanism initiated by classically activated, or M1, macrophages is clearly beneficial for survival of the organism. However, to resolve the infection or injury and restore normal tissue homeostasis, the innate immune response to injury requires replacement of lost and damaged cells and restructuring of the damaged extracellular matrix (ECM). Thus, it is not surprising that mechanisms to reduce the defense response and promote repair and resolution of the wound are components of innate immunity. Repair and resolution do not result simply from passive decay of the initiating signals. Reducing bacteria levels at the wound site and increasing catabolism of proinflammatory mediators will decrease both activation of the pattern recognition receptors and bystander injury caused by proinflammatory cytokines. However, wound healing represents a second stage of the innate immune response that generally arises from the initial immune stimulus.

Table 1 lists mechanisms that can curb macrophage classical activation and thus limits the proinflammatory state. Although many of these mechanisms might be used in the brain's innate immune response, tissue-specific differences are likely. For example, tissue invasion of
Table 1 General mechanisms that promote resolution of an innate immune response to injury or infection

Reduction in pathogen load

Catabolism of proinflammatory mediators

Disposal of activation immune cells

Apoptosis of macrophages

Clearance via lymphatic drainage or vasculature

Negative feedback control over activation pathways

Loss of TLR/other receptors

Ubiquitination and degradation

Decreased expression

Activity of negative regulatory proteins

Proteins tyrosine phosphatase family (CD45, PTEN, SHIP)

Inducible suppressions of cytokine signaling (SOCS)

NF-KB pathway inhibitors (A20, IKK phosphorylation)

Decoy and soluble receptors/ligands

Micro-RNAs

Neuronal factors (acetylcholine, NPY, norepinephrine)

Altered regulation of macrophage functional phenotype

Alternative activation

Acquired deactivation

monocytic cells in the periphery is important for reducing the proinflammatory signal during the second stage of the immune response. After infiltration into injury sites, these newly recruited macrophages phagocytose dead or dying immune cells (van Rossum et al. 2008) then exit the tissue via the lymphatic system and are rapidly dispersed throughout the vasculature and eventually removed from circulation. Removal of the proinflammatory immune cells then allows the "injured" tissue to slowly return to its previous state. Movement of cells and solutes from blood vessels to the brain parenchyma across the blood-brain barrier takes place differently than it does across peripheral blood vessels. Under physiological conditions, the restriction of paracellular flux by endothelial cell tight junctions not only reduces solute transfer but also restricts movement of cells, such as circulating monocytes and lymphocytes, across the blood-brain barrier (Abbott et al. 2006). Injury and disease, however, may alter blood-brain barrier function and increase peripheral cell invasion (Soulet and Rivest 2008). Despite cerebral ischemia that is known to damage the blood-brain barrier, Denker et al. (2007) and Schilling et al. (2005) have independently shown that resident microglia and not infiltrating macrophages are the predominant cell type at the ischemic injury site. Other entry sites for blood-borne cells such as the choroid plexus, however, may also be a factor during brain injury (Reboldi et al. 2009). One point of caution, recent studies by Mildner et al. (2007) and Ajami et al. (2007) have shown that the techniques commonly used to study this phenomenon can be flawed, making interpretation of disparate data more 
difficult. More detail on this highly controversial area of research is provided in several excellent reviews (Pachter et al. 2003; Soulet and Rivest 2008; Villoslada et al. 2008; Schwartz et al. 2009).

Likewise, phagocytic macrophages are unlikely to exit the brain parenchyma via the lymphatic system. The limited permeability of the blood-brain barrier reduces the tissue pressure that favors fluid movement into the brain parenchyma. This situation contrasts with that of the periphery, where bulk flow moves substantial amounts of fluid across capillaries into tissues, and excess fluid gets removed via lymphatic drainage and replaced into the vasculature. The brain not only lacks a defined lymphatic system but has very low levels of protein in the interstitial fluid, thus limiting fluid movement into the brain (Abbott 2004; Boulton et al. 1998; Weller et al. 2008). Drainage of some brain interstitial fluid does occur in the perivascular spaces between blood vessel walls and brain parenchyma (Carare et al. 2008; Weller et al. 2008). This drainage depends on cardiac output and allows fluid to exit the brain along the surface of the basement membranes of the arterial system. Proteins injected into the cerebral spinal fluid (CSF) of the lateral ventricles also find their way out of the brain via lymphatic drainage. Boulton et al. (1996) have shown that ligating cervical and thoracic lymph nodes reduced appearance of the protein tracer in the blood. Clearly, interconnecting pathways between the CSF and lymph exist. While soluble proteins may enter circulating blood via this system, removal of macrophagic cells from the brain is unlikely (Carare et al. 2008). Thus, reducing proinflammatory microglia by apoptosis and engulfment via newly recruited monocytes are unlikely to be important mechanisms for inactivating the innate immune response in the brain.

\section{Downregulation of classical activation: feedback reduction of signaling pathways}

Classical activation is also reduced in macrophages by inherent feedback signals that regulate specific steps in the activation process (Table 1). In some cases, these regulatory proteins are made when the surface pattern recognition receptors are activated, or they may be constitutively expressed in the immune cell (Han and Ulevitch 2005; Serhan and Levy 2003; Ulevitch et al. 2004). For example, production of TRIAD3, which mediates ubiquitination and subsequent degradation of TLRs, reduces TLR levels on surface membranes (Chuang and Ulevitch 2004). Responsiveness of the immune cell to pathogens drops accordingly. Competition between functional and nonfunctional adaptor proteins such as MyD88 and a splice variant of MyD88 (MyD88s) has been shown to reduce TLR signaling, while adaptor proteins such as Toll inhibitor protein, which sequester a corresponding signaling protein, also downregulate proinflammatory signaling pathways (Zhang and Ghosh 2002). Suppressor of cytokine signaling proteins is an additional family of regulatory proteins that depress the IFN- $\gamma$ activation pathway at multiple points (see review by Baetz et al. 2004). Interestingly, CD45, a marker commonly used to identify "activated" microglia in the brain, is a protein tyrosine phosphatase that inhibits JAK family kinases (Townsend et al. 2004). Activation of the CD45 phosphatase by cross-linking with an anti-CD45 antibody reduces lipopolysaccharide (LPS)-mediated proinflammatory signaling in microglia (Tan et al. 2000). However, studies with CD45 knockout mice have revealed more complex actions of the tyrosine phosphatase that may include sustaining inflammation under some circumstances by "resetting" kinases via removal of phosphate groups (Abbas et al. 2002).

Recently, noncoding RNA oligonucleotides (microRNA or miRNA) have been shown to regulate gene expression by binding to $3^{\prime}$ untranslated regions of specific target genes (Tili et al. 2007; Valencia-Sanchez et al. 2006). Microarray analysis has detected significantly increased expression of at least three miRNAs when macrophages are stimulated with TNF- $\alpha$, Poly I:C, or LPS (O'Connell et al. 2007). One of these, miR 146, has been shown to reduce expression of TRAF6 and other proteins involved in nuclear factor (NF)- $\mathrm{KB}$ signaling and to reduce the production and release of NF- $\mathrm{KB}$-regulated cytokines. Though their mechanism of action is not yet clear, miRNAs provide an interesting means to alter the extent and timing of the proinflammatory phase of the innate immune response (Tili et al. 2007).

Once proinflammatory mediators are produced and released into the extracellular environment, their effectiveness and bioavailability can be altered to reduce the proinflammatory response. For example, the IL-1 receptor family has specific decoy receptors, expressed on the macrophage surface or secreted into the local environment, that reduce autocrine or paracrine feedback stimulation of the cells. In macrophages, exposure to LPS or IL-1 upregulates levels of IL-1RII, a nonfunctional receptor for IL- $1 \alpha$ and IL- $1 \beta$ that binds IL-1 but fails to trigger intracellular signaling (Han and Ulevitch 2005;Pousset et al. 2001). IL-1RII exists in membrane-bound and secreted forms, and recent data suggest that alpha- (BACE1), beta- (BACE2), and gammasecretase activity contributes to production of the soluble form (Kuhn et al. 2007). Garlind et al. (1999) have shown that soluble IL-1RII levels are increased in the CSF of AD patients compared to age-matched control individuals. IL receptor antagonist (IL-1Ra) is a soluble nonfunctional ligand of the IL-1 receptor family that also reduces IL1-mediated proinflammatory signaling (Pousset et al. 2001). In addition, soluble receptors for other cytokines such as 
IL- 6 and TNF- $\alpha$ are shed to the extracellular matrix where they compete with the functional membrane receptor for cytokine binding and effectively reduce cell signaling (Han and Ulevitch 2005; Kariko et al. 2004; Pousset et al. 2001; Serhan and Levy 2003).

\section{Repair and resolution: changing the macrophage activation state}

A powerful way to stop the "killing" phase of classically activated macrophages and to restore tissue homeostasis after injury is to change the macrophage activation state away from a proinflammatory gene profile to a gene profile that supports repair and tissue reconstruction. The switch to an alternatively activated state is induced by multiple factors, including cytoactive agents released during the classical response and/or by $\mathrm{T}_{\mathrm{H}} 2$ regulatory cells recruited to the injury site. Anti-inflammatory cytokines are the predominant induction signal (Hamilton et al. 1999; Martinez et al. 2008; Sandler et al. 2003; Scotton et al. 2005). Derived primarily from studies in peripheral tissues, four major anti-inflammatory cytokines have been identified: IL-4, IL-13, IL-10, and TGF- $\beta$ (Bogdan et al. 1991; Hamilton et al. 1999; Gordon and Taylor 2005; Martinez et al. 2008; Mills et al. 2000). Stimulation of peripheral macrophages with IL-4, IL-13, IL-10, or TGF- $\beta$ antagonizes classical activation pathways and induces new genes and proteins involved specifically in tissue repair and reconstruction. Other cytoactive factors, such as glucocorticoids and type 1 interferons (interferon alpha; interferon beta), also suppress proinflammatory gene induction. While much is known about the source of anti-inflammatory cytokines that initiate repair and resolution in the periphery, less is known in the CNS. $\mathrm{T}_{\mathrm{H}} 2$ regulatory cells may not be the common source. Instead, IL-4, IL-13, TGF- $\beta$, and IL-10 are each produced within the brain and are released by either microglia, astrocytes, or, in some cases, neurons (Brodie et al. 1998; Finch et al. 1993; Glezer et al. 2007; Grommes et al. 2008; Ledeboer et al. 2000; Morgan et al. 1993; Shin et al. 2004; Suzuki et al. 2005; Szczepanik et al. 2001). The signal for their production is thought to be the original pathogens and/or secondary factors secreted as a result of paracrine or autocrine activity. However, particularly for IL-4 and IL-13 (Ponomarev et al. 2007), messenger RNA (mRNA) and protein levels are highly variable and they may be found only under specific types of induction. Expression levels may also vary depending on brain region. For example, microglia around the cerebrovasculature (perivascular microglia) may be exposed to higher levels of IL-4 or IL-10 from encounters with activated $\mathrm{T}$ cells or regulatory $\mathrm{T}$ cells that have traversed the blood-brain barrier to enter the brain parenchyma around the blood vessels (Perry et al. 2007; Schwartz et al. 2009; Tiemessen et al. 2007; Villoslada et al. 2008).

To distinguish the "repair/resolution" state of macrophages from the "killing" phase associated with classical activation (also denoted as ca $\Phi$ or M1 macrophages), the term alternative activation (or aaMac) has been recently adapted for peripheral macrophages. The term was originally derived from the association of this macrophage state with the $\mathrm{T}_{\mathrm{H}} 2$ adaptive immune responses and, hence, the term M2 has also been used to describe alternatively activated macrophages (Edwards et al. 2006; Mantovani et al. 2002; Mills et al. 2000; Mosser 2003). However, recent studies have suggested that applying a single nomenclature to macrophages exhibiting repair activation states does not adequately describe the differences between macrophages with this general functional phenotype. To partially remedy this problem, Simon Gordon (2003; Gordon and Taylor 2005) has proposed to restrict the use of "alternative activation" to describe macrophages exposed primarily to IL-4 or IL-13. Accordingly, a third subtype of macrophage activation has been identified and has been termed "acquired deactivation" by Gordon (2003; Gordon and Taylor, 2005). The acquired deactivation subtype incorporates a mixed-phenotype population that exhibits immunosuppression and is associated with uptake of apoptotic cells. Acquired deactivation is distinguished from alternative activation by the type of induction agents and by the functional changes associated with induction. In this case, IL-10 by itself or in addition to TGF- $\beta$ initiates cell signaling pathways that result in the inhibition of proinflammatory cytokine production, increased expression of scavenger receptors and further increased IL-10 production. In addition, major histocompatibility complex (MHC) class II antigens and their costimulatory proteins are suppressed, making this macrophage subtype less effective at presenting antigen to invading T cells (Gordon 2003; Williams et al. 1996). The signaling mechanisms for IL-10 require STAT3 and, for TGF-B, Smad (Li et al. 2006; Ricchetti et al. 2004; Williams et al. 2007). Acquired deactivation can also be induced by the phagocytosis of apoptotic cells, which is known to increase production of TGF- $\beta$ and IL-10 (Freire-deLima et al. 2006; Gregory and Devitt 2004; Griffiths et al. 2009; Li et al. 2006). Although the above definitions of alternative activation are not universally accepted, Table 2 provides known characteristics of each macrophage phenotype including induction agents, functions, and key genes mediating those effects.

\section{Alternative activation}

Alternatively activated macrophages (aaMac) are characterized both by the absence and by the presence of specific 
Table 2 Identifying features of microglial activation states

\begin{tabular}{|c|c|c|c|c|c|}
\hline $\begin{array}{l}\text { Activation } \\
\text { state }\end{array}$ & $\begin{array}{l}\text { Specific } \\
\text { induction } \\
\text { agent }\end{array}$ & $\begin{array}{l}\text { Primary } \\
\text { signaling } \\
\text { mediator }\end{array}$ & $\begin{array}{l}\text { Identifying } \\
\text { antigens }\end{array}$ & $\begin{array}{l}\text { Shared } \\
\text { antigens }\end{array}$ & General functions \\
\hline $\begin{array}{l}\text { Classical } \\
\text { activation }\end{array}$ & $\mathrm{IFN}-\gamma$ & $\begin{array}{l}\text { STAT1 } \\
\text { (STAT4) }\end{array}$ & $\begin{array}{l}\text { IL-12p40, MARCO TNF- } \alpha \text {, } \\
\text { IL-6, IL-1b }\end{array}$ & $\begin{array}{l}\text { MHCII, C-type lectins, } \\
\text { CAT2 }\end{array}$ & $\begin{array}{l}\text { Tissue defense, proinflammatory } \\
\text { cytokine production, NO } \\
\text { production }\end{array}$ \\
\hline $\begin{array}{l}\text { Alternative } \\
\text { activation }\end{array}$ & IL-4, IL-13 & STAT6 & $\begin{array}{l}\text { MR, AG1, ym1/Chi3L1/L2, } \\
\text { lack of NOS2, DC-SIGN, } \\
\text { FIZZ1 }\end{array}$ & $\begin{array}{l}\text { MHCII, CD163, CD36, } \\
\text { C-type lectins, CAT2, } \\
\text { IL-1Ra }\end{array}$ & $\begin{array}{l}\text { Tissue repair, anti-inflammatory } \\
\text { cytokine production, fibrosis, } \\
\text { ECM reconstruction }\end{array}$ \\
\hline $\begin{array}{l}\text { Acquired } \\
\text { deactivation }\end{array}$ & $\begin{array}{l}\text { TGF- } \beta, \text { IL- } \\
10, \text { apoptotic } \\
\text { cells }\end{array}$ & $\begin{array}{l}\text { STAT3 } \\
\text { SMAD }\end{array}$ & $\begin{array}{l}\text { sphk-1/2 IL-4R } \alpha \text {, high IL-10, } \\
\text { SOCS3, CCL18 }\end{array}$ & $\begin{array}{l}\text { CD163, CD36, C-type } \\
\text { lectins, low MHCII, IL- } \\
\text { 1Ra }\end{array}$ & $\begin{array}{l}\text { Immunosuppression, oxLDL and } \\
\text { apoptotic cell uptake }\end{array}$ \\
\hline
\end{tabular}

$I F N-\gamma$ interferon $\gamma, I L-12 p 40$ interleukin 12 p 40 subunit, $T N F$ - $\alpha$ tumor necrosis factor $\alpha, I L-6$ interleukin $6, I L-1 \beta$ interleukin $1 \beta, M H C I I$ major histocompatibility antigen II, CAT2 cationic amino acid transporter 2, NOS2 nitric oxide synthase 2, NO nitric oxide, TGF- $\beta$ transforming growth factor $\beta, I L-10$ interleukin 10, sphk sphingosine kinase, $I L-4 R \alpha$ interleukin 4 receptor $\alpha, S O C S 3$ suppressor of cytokine signaling 3 , CCL-18 chemokine 18,IL-1Ra interleukin 1 receptor antagonist, $I L-13$ interleukin 13, MR mannose receptor, $A G 1$ arginase 1, YM-1 mouse homolog chitinase 3 like 1 (CHI3L1), DC-SIGN dendritic cell-specific intracellular adhesion molecule 3-grabbing integrin, FIZZ1 found in inflammatory zone 1, ECM extracellular matrix, MARCO macrophage receptor with collagenous structure

genes whose expression levels change during the switch from a proinflammatory to an anti-inflammatory state after injury or infection. The cellular mechanisms that govern this switching process are currently unknown, and redundant mechanisms are likely, thus ensuring that resolution and repair occurs. Interestingly, many parasitic organisms have subverted alternative activation as a means to enhance their survival within cells or tissues (Noel et al. 2004; Raes et al. 2007; Vincendeau et al. 2003; Wynn et al. 2004). Compared to classically activated macrophages, alternatively activated macrophages do not express high levels of proinflammatory cytokines. Instead, NOS2, IL-12, IL-1 $\beta$, IL-6, and TNF- $\alpha$ mRNA and protein levels in LPSstimulated microglia and mixed glial cultures are suppressed by IL-4 and IL-13 (Colton et al. 2006a; Kitamura et al. 2000; Ledeboer et al. 2000; Lee et al. 2002; Lyons et al. 2007b; Ponomarev et al. 2007). In general, either IL13 or IL-4 stimulation of macrophages results in a similar gene profile. Scotton et al. (2005) have provided a detailed analysis of gene expression in IL-13-treated human monocytes. Although their signaling pathways diverge, IL-13 and IL-4 share the IL-4 receptor $\alpha$ subchain (IL-4R $\alpha$ ). Upon binding to the receptor, IL-13 or IL-4 activates the JAK1 kinase, resulting in phosphorylation of the IL-4R $\alpha$ cytoplasmic tail. STAT6 is then recruited to the receptor where it is phosphorylated and subsequently translocates to the nucleus (Scotton et al. 2005). Like other STAT proteins, STAT6 binds DNA and can rapidly transduce membrane signals to gene induction during inflammation. The importance of STAT6 to the gene switch is shown in studies on knockout mice where the genetic removal of STAT6 results in lost responsiveness to IL-4 or IL-13 and failure to induce the alternative activation state (Pfitzner et al. 2004; Zhu et al. 2001).
Again, the majority of studies on IL-4 and IL-13's action on macrophage functional states have used peripheral macrophages while IL-4- and IL-13-mediated responses in the brain have not been widely investigated and remain poorly understood. IL-4 receptors are found on microglia and astrocytes and are expressed at high density on multiple types of glial tumors (Kawakami et al. 2001). IL-13 receptors are found in rat and human brain, suggesting that IL-13 signaling is also observed in the brain (Lee et al. 2002; Wu et al. 2008). Our laboratory has shown that microglia demonstrate an anti-inflammatory alternative activation phenotype when stimulated with IL- 4 or IL-13. Treatment of IFN- $\gamma$-activated BV2 microglia or primary mouse microglia in culture with IL-4 or IL-13 significantly reduced NOS2 and TNF- $\alpha$ mRNA expression. Repair genes, in contrast, were increased. IL-4 or IL-13 treatment of microglia resulted in increased mRNA expression of arginase 1 (AG1), mannose receptor (MRC1), found in inflammatory zone 1 (FIZZ1), and Ym1 (Colton et al. 2006a; Lyons et al. 2007a). In addition, treatment with $A \beta$ peptides plus IL-4 increased microglial expression of AG1 by approximately $70 \%$ compared to IL-4 alone, suggesting that $\mathrm{A} \beta$ may directly regulate some components of alternative activation. Using $A \beta$ peptides as the immune stimulus, Lyons et al. (2007a) and Lee et al. (2002) have shown that IL-4 reduces $A \beta$-mediated proinflammatory gene expression in microglia in vitro and in vivo.

Just as proinflammatory genes are downregulated, specific cytokine and growth factor genes are upregulated in IL-4-treated macrophages. Increased mRNA expression is found for IL-10, TGF- $\beta$, CD23 (the low-affinity IgE receptor, FceRII), insulin growth factor 1 (IGF-1), nerve growth factor (NGF), and peroxisome proliferation activation receptor gamma (PPAR- $\gamma$; Brodie et al. 1998; 
Kitamura et al. 2000; Odegaard et al. 2007; van Rossum et al. 2008). These genes are generally associated with the continued physiological requirements for repair and reconstruction after injury, including adaptive immunity and metabolism. The PPAR family contains PPAR- $\alpha, \delta$, and $\gamma$, ligand-activated transcription factors whose distinct expression patterns and ligand specificities mediate different biological functions through targeting of genes associated with energy metabolism (Odegaard et al. 2007). PPAR- $\gamma$ upregulates expression of genes involved in high-density lipoprotein metabolism, downregulates cholesterol esterification, and inhibits the production of inflammatory mediators. Although tissue-specific differences have been observed, Odegaard et al. (2007) have recently shown that IL-4mediated upregulation of alternative activation genes depends highly on PPAR- $\gamma$. Gene screens of IL-13-treated cells have shown a threefold to fourfold increase in PPAR- $\gamma$ mRNA expression (Scotton et al. 2005). Upregulation of IGF-1 and its insulin-like regulation of glucose during alternative activation further couples metabolism to repair (Rajpathak et al. 2009). Finally, IL-4 or IL-13 treatment increases CD23 expression in human macrophages. While CD23 deficiency leaves mice with higher circulating levels of IgE, IL-4-induced CD23 overexpression is generally believed to depress IgE levels and downregulate allergictype reactions during chronic disease (Ford et al. 2006).

\section{Lectins and alternative activation-mannose receptor}

Highly branched complex polysaccharides (e.g., mannose, $\mathrm{N}$-acetylglucosamine, or sialic acid) are frequently expressed by pathogens such as bacteria and fungi or by proteins such as lysosomal hydrolases released from dying cells. These carbohydrate moieties are recognized by specific lectin binding sites on the macrophage membrane and, when bound, initiate signaling pathways within the macrophage (Taylor et al. 2005b). Multiple subtypes of lectin binding sites have been described (Taylor et al. 2005a) and include the mannose receptor (MR, MRC-1, CD206). MR is a member of the C-type lectin family and is not expressed on classically activated macrophages. Instead, it is a characteristic antigen of the alternatively activated state.

In general, binding of the macrophage MR to its ligand initiates MR receptor cross-linking, followed by phagocytosis of the ligand and activation of a typical antiinflammatory signaling pathway that results in decreased IL-12 and TNF- $\alpha$ and increased IL-10 and IL-1Ra mRNA and protein expression (Chieppa et al. 2003; Kerrigan and Brown 2009; Pachter et al. 2003; Taylor et al. 2005a). MR activation is also critical for upregulation of MHC II expression and antigen presentation and helps to link innate and adaptive immunity. Interestingly, Linehan et al. (1999, 2003) and Galea et al. (2005) have shown that MR expression in the brain is found primarily on perivascular microglia, a subtype of brain macrophages long known to have unique characteristics (Perry and Gordon 1988). Their location at the brain-vasculature interface implies that enhancement of antigen presentation by MR activation at this site may be important in brain disease. This location is likely to be more accessible to T-regulatory cells or other cells associated with the adaptive immune response (Soulet and Rivest 2008). That perivascular microglia also express high levels of CD163 (Fabriek et al. 2005), the membrane scavenger receptor associated with uptake of hemoglobin/ haptoglobin complexes, also supports a role for this type of microglia in brain disease, as it suggests that these cells may be exposed to hemoglobin leaked from blood during microhemorrhage. CD163 expression is increased by IL-10 (Fabriek et al. 2005; Schaer et al. 2002). Both MR and CD163 are cleaved by metalloproteases and shed from the surface membrane, which could make it difficult to see changes in expression levels using immunocytochemistry, particularly in disease states where levels of matrix metallopeptidase 9 and other collagenases are increased.

Other lectins such as dectin 1 and 2 and DC-SIGN also play important roles in macrophage activation (Kerrigan and Brown 2009; Taylor et al. 2005c). The polysaccharide ligands for these receptors are highly varied but can be found in most tissues. For example, Lewis $\mathrm{X}$ trisaccharides, a component of the lacto- $N$-fucopentose III glycan from parasites such as Schistosoma, are extremely potent inducers of alternative activation in macrophages (Atochina et al. 2008). Similar glycan moieties are found in brain fucolipids, which are glycosphingolipids containing fucose (Taketomi et al. 1984). Chitin, an $N$-acetyl-B glucosaminebased component of molting worms and insect exoskeletons, initiates alternative activation of lung macrophages (Reese et al. 2007) and accumulates around brain amyloid deposits (Castellani et al. 2005; Sotgiu et al. 2008). Proteins associated with chitin degradation (chitinase 3 like 1; see below) are also upregulated in $\mathrm{AD}$, but their role in the brain remains largely unknown.

Of the many lectins found in the brain, dectin 1 is particularly interesting because of its regulation by IL-4 and IL-13. Dectin 1 was originally described as a dendritic cell receptor but more recently has been found on membranes of tissue macrophages, including microglia (Shah et al. 2008; Taylor et al. 2005c; Willment et al. 2003). In contrast, dectin 2 is primarily found on dendritic cells and some peripheral macrophages but not on brain microglia (Taylor et al. 2005c). Similar to MR, dectins are a subtype of C-type lectins and bind to beta 1,3 glucan, chitin, mannan residues, and zymosan - pathogen moieties that are commonly associated with fungi, including yeast. Dectin 1 
mRNA and protein expressions on peripheral macrophages are increased by treatment with IL-4 or IL-13 (Willment et al. 2003). However, instead of a downregulatory response typical of IL-4 stimulation, dectin 1 activation by IL-4 leads to TNF- $\alpha$ production and a subsequent proinflammatory secretory response that includes NADPH oxidase-mediated production of superoxide anions (Shah et al. 2008; Underhill 2007). On the other hand, beta-glucanmediated activation of dectin 1 on microglia produced an abbreviated response without proinflammatory cytokine and chemokine secretion (Shah et al. 2008), although production of superoxide anion was still observed. It is not yet clear why or how dectin 1 stimulation produces these tissue-specific effects.

\section{Arginase-NOS2 balance in alternative activation}

Increased arginase The pattern of gene induction in alternatively activated macrophages clearly indicates that repair is a major function of this macrophage state. For example, expression of arginase $\mathrm{I}(A G)$ is selectively increased in aaMacs and can be used as a distinguishing feature of alternative activation. Arginine is utilized in multiple enzymatic pathways whose differential activation in tissues throughout the body provides a cell-specific system for arginine metabolism (Fig. 1; Morris 2004a, b, 2007). In the brain, the primary enzymes that require arginine as the sole substrate are arginase and NOS, although arginine is also used to produce agmatine via arginine decarboxylase and for protein synthesis. The enzymatic action of NOS to produce citrulline and NO from the oxidation of arginine is now well-known (Marletta 1994; Moncada and Higgs 1991), and all three enzymes that produce NO are found in the brain (Wiesinger 2001). Arginase expression and activity in the brain are less well known. Two isoforms of arginase are found: arginase I, an inducible cytoplasmic form; and arginase II, a constitutively expressed isoform believed to be localized to mitochondria (Braissant et al. 1999; Cederbaum et al. 2004; Salimuddin et al. 1999; Yu et al. 2001, 2003). Arginase I is robustly expressed in the cerebellum, pons, medulla, and spinal cord with lower expression in the hippocampus and the entorhinal and temporal cortices, whereas arginase II appears to be expressed throughout the brain at a low level (Yu et al. 2003). The enzymatic product of both the cytosolic and mitochondrial forms of arginase is ornithine. In mitochondria, ornithine is metabolized by ornithine aminotransferase and contributes to glutamate, proline, and hydroxyproline formation. Hydroxyproline is an essential component of collagen synthesis. In peripheral tissues, collagen is a major component of ECM that helps to physically strengthen the tissue but is also used for repair at sites of injury. However, as discussed in more detail below, collagen is not a dominant feature of the ECM in the brain, as it is only found around the cerebrovasculature (Busch and Silver 2007).

Arginase-induced ornithine production also leads to increased polyamine levels. Polyamines (putrescine, spermidine, and spermine) are multivalent cations essential for cell proliferation and differentiation (Thomas and Thomas 2001; Wallace et al. 1981; Wallace et al. 2003). For example, polyamines interact with DNA to promote stabilization and condensation and, consequently, cell proliferation (Thomas and Thomas 2001). While generalized cell proliferation is not a major factor in brain repair due to the postmitotic state of mature neurons, altered neurogenesis in specific proliferative areas of the brain contribute to the replacement of neurons. Polyamines have recently been shown to stimulate neuronal progenitor proliferation in the subgranular zone of the dentate gyrus and subventricular zone (Malaterre et al. 2004). Finally, spermine can help protect neurons injured by exposure to proinflammatory cytokines by blocking NMDA channels
Fig. 1 Arginase-NOS2 balance. Arginine is taken up by arginine transporters where it is used by both arginase 1 and nitric oxide synthase. Arginase pathways produce polyamines and ECM while NOS pathways produce $N$-hydroxy arginine (an inhibitor of arginase (N-OH-arg)), nitric oxide (NO), and citrulline

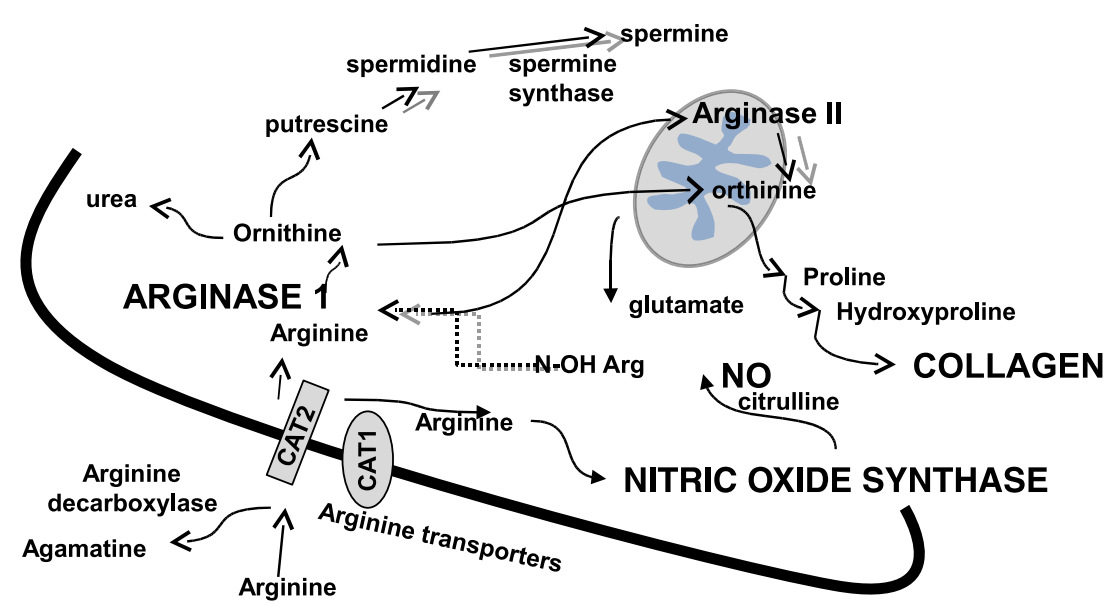


and/or altering GluR1 and potassium (K) channel function (Williams 1997).

Decreased NOS2 Macrophages and other cell types (neurons, endothelial cells, astrocytes) that coexpress NOS and arginase demonstrate a reciprocal relationship between NO production and ornithine production during the innate immune response. The inverse association of arginase and NOS is based on the requirement of these two enzyme systems for arginine, the sole substrate of each enzyme (Morris et al. 1998; Morris 2004b). Essentially, NOS and arginase compete for available intracellular arginine. While this does not seem likely based on $\mathrm{Km}$ values for the two enzymes $(\mathrm{Km}$ NOS $=3-10 \mu \mathrm{M}$; Km arginase $=3-10 \mathrm{mM})$, the time course of induction and the 1,500-fold greater Vmax of arginase gives ornithine formation an advantage over NO production. Thus, NO levels fall when arginase activity is high. Alternative activation is also characterized by IL-4- or IL-13-mediated reduction of NOS2 mRNA and protein expression. Since NO-mediated nitrosylation, nitrosation, and nitration of bacterial proteins is an efficient way to kill bacteria (Ogawa et al. 2001; Ren et al. 2008), loss of NOS2 and NO reduces the effectiveness of the innate immune response against bacteria and virus. However, NOS2 suppression and reduced NO production also limit self-damage (bystander injury) caused by high localized levels of $\mathrm{NO}$ and reactive nitrogen oxygen species $\left(\mathrm{N} 2 \mathrm{O} 3, \mathrm{NO} 2, \mathrm{ONOO}^{-}\right)$. This action of NO is now well described and includes induction of P53, damage to mitochondria, and oxidative and nitrosative damage to multiple cell proteins (Ridnour et al. 2004; Thomas et al. 2008; Wink et al. 1996).

Despite the loss of NOS activity, utilization of arginine by alternatively activated macrophages continues at a high rate. This is due, in part, to the concomitant loss of an endogenous inhibitor that regulates arginase activity, N$\mathrm{OH}$-arginine, which is formed by an early oxidation step in the conversion of arginine to citrulline (Buga et al. 1996; Morris 2007; Fig. 1). In addition, cationic amino acid transporters in the macrophage membrane that supply cells with intracellular arginine are increased in number and activity by LPS stimulation (Closs et al. 2006). Cationic amino acid transporter 2 (CAT2; SLC7A2) expression is significantly increased in both alternatively and classically activated macrophages (Yeramian et al. 2006a, b). CAT1 (SLC7A1), the constitutive form of the arginine-selective transporter family, has been reported to be downregulated by TGF- $\beta$, insulin, and glucocorticoids in some cell types and upregulated in others (Liu and Hatzoglou 1998; Durante et al. 2001). Both microglia and astrocytes in culture have been shown to express both inducible and constitutive forms of arginine transporters (Czapiga and Colton 2003; Manner et al. 2003). Furthermore, our laboratory has shown that arginine transport by cultured microglia can be modified by APOE genotype, such that arginine uptake is greater in APOE4/4 microglia compared to microglia cultured from APOE3/3 mice (Czapiga and Colton 2003).

\section{Extracellular matrix and alternative activation of microglia}

Components of the ECM have the capacity to regulate the activation state of macrophages and microglia and bind to the same PRRs that are used by pathogens (Morwood and Nicholson 2006). ECM is composed of three types of proteins, which include both protein-bound and unbound glycosaminoglycans (known as proteoglycan and hyaluron, respectively), fibrous proteins (e.g., collagens), and proteins that provide elasticity to the matrix (e.g., fibronectin and elastins). The brain ECM contains all three, but the levels of these components are different than levels found in peripheral tissues. For example, the amount of collagen in the brain is lower than in other tissues, and its distribution is restricted to special locations in the adult brain that include the basement membranes around the cerebrovasculature, the dura mater, and leptomeninges (Busch and Silver 2007; Galtrey and Fawcett 2007; Morwood and Nicholson 2006). The most abundant proteins in the brain's ECM are GAGs, particularly hyaluronan, which is composed of a protein core with repeating units of disaccharides. Crosslinked hyaluronan serves as a backbone for the perineuronal net that surrounds neurons in specific brain regions (Galtrey and Fawcett 2007).

Proteolytic cleavage fragments of ECM proteins serve as ligands for PRRs and are produced during the initial stages of injury by the action of multiple proteases, including collagenases (also known as matrix metalloproteases). Although generally not considered as a major factor in the innate immune response, ECM-based ligands in all tissues can both upregulate and downregulate immune signaling (Morwood and Nicholson 2006; Taylor and Gallo 2006). Ebert et al. (2008) have shown that treatment of BV2 or primary microglia with varying concentrations of CSPG-DS (a disaccharide degradation product of chondroitin sulfate proteoglycan) blocked IFN- $\gamma$-mediated NO production and increased phagocytosis of latex beads.

Induction of alternative activation after injury by chondroitin-based proteoglycans may be important for establishing repair processes. Two genes that can be used to characterize the alternative activation state, FIZZ1 and YM1, are associated with reconstruction of extracellular matrix (Raes et al. 2002a, b). FIZZ1 encodes a 9.4-kDa cysteine-rich protein that is induced by IL-4, IL-13, and IL- 
21, a newly described cytokine that shares significant homology with IL-4 (Colton et al. 2006a; Raes et al. 2005; Stutz et al. 2003). FIZZ1 (also known as RELM-A) is a member of a family of resistin-like molecules (RELM) and increases collagen expression and myofibroblast differentiation (Liu et al. 2004). It has also been linked to an interaction between NGF and neurons in the lung, but its role in the CNS injury response is unknown.

Ym1 (Chi3-L3) is a novel mammalian lectin that was discovered as a secretory product of mouse peritoneal macrophages in response to nematode infections (Hung et al. 2002). However, multiple tissues including the brain express Ym1 during an immune response. For example, $\mathrm{Ym} 1$ expression was transiently induced in microglia over 3 days and was gone by day 6 after a stab wound (Hung et al. 2002). Our studies have shown that Ym1 mRNA increases in IL-4- or IL-13-stimulated BV2 cells in vitro (Colton et al. 2006a). The functions of Ym1 are not well known but are believed to involve its ability to bind heparin sulfate. Heparin sulfate serves as a docking site for growth factors in the ECM and is degraded by heparinases during inflammation. By binding to heparin, Ym1 is believed to slow the loss of growth factors that may be required for rebuilding of the tissue (Raes et al. 2002a). Direct human homologs have not been identified for $\mathrm{Ym1}$, but two closely related genes, CHI3L1 and CHI3L2, are found in human tissues including the brain (Colton et al. 2006a; Rehli et al. 1997). CHI3L1 (also known as HC-gp 39 or YKL-40) and its close homolog, CHI3L2 (YKL-39), are members of a large family of human chitinases that are nonhydrolytic and thus do not function as enzymes (Rehli et al. 1997). CHI3L1 and 2 are produced by macrophages and are induced during an alternative activation state where they are believed to participate in reconstruction of ECM (Recklies et al. 2002). In brain, CHI3L1 is a characteristic marker of glioblastoma (Junker et al. 2005), suggesting that glial tumors, similar to some cancers in the periphery, may be associated with alternatively activated macrophages.

\section{Alternative activation and phagocytosis}

IL-4 and IL-13 regulate macrophage phagocytosis but can result in either increased or decreased uptake depending on the profile of "phagocytic" receptors expressed on the macrophage membrane. For example, FcRI, FcRII, and CD163 expression levels are reduced by IL- 4 while MR, complement receptor 3, and dectin 1 are increased (Gordon 2003; Nimmerjahn and Ravetch 2006; Schaer et al. 2002; Willment et al. 2003). Costimulatory factors also affect the level of phagocytosis observed in alternatively activated macrophages. Gratchev et al. (2005) have shown that IL-4treated peripheral macrophages increase phagocytosis of latex beads compared to IFN- $\gamma$ treatment, which does not promote phagocytosis. However, IL-4 in combination with other cytoactive factors such as colony-stimulating factor (CSF) or glucocorticoids (dexamethasone) reduces particle uptake (Gratchev et al. 2005; Leidi et al. 2009). The reduction of phagocytosis when IL-4 and dexamethasone are both present is surprising since glucocorticoids dramatically increase phagocytosis. Thus, IL-4 can apparently bypass glucocorticoid's actions on phagocytosis. While the mechanism of this process is unknown, it may involve IL4-mediated suppression of specific phagocytic receptors. Glucocorticoid-mediated stimulation of phagocytosis is due, in part, to increased expression of MARCO, a scavenger receptor from the SR-A family (Taylor et al. 2005b). Although constitutive expression has been found in some tissues, MARCO is also highly upregulated by activation of TLRs and by treatment with IFN- $\gamma$ and is thus associated with classical activation. Simultaneous treatment of IL-4 plus dexamethasone reduced MARCO expression but not back to the levels observed in macrophages treated with IL-4 alone (Gratchev et al. 2005). Equivalent studies have not yet been done on microglia but are extremely important to understanding how alternative activation can affect uptake and removal of pathogens such as amyloid deposits in the brain.

\section{Acquired deactivation}

Acquired deactivation is the second macrophage activation state associated with an anti-inflammatory and repair functional phenotype. Alternative activation and acquired deactivation both downregulate innate immune responses and, not surprisingly, demonstrate similar, but not identical, gene profiles. As mentioned previously, many investigators have merged alternative activation and acquired deactivation into a single category (most commonly called M2 or alternative activation). However, the changes in macrophage activation state induced by IL-4 and IL-13 can be distinguished from acquired deactivation. The most prominent difference is that acquired deactivation is induced by exposure of macrophages to apoptotic cells or to TGF- $\beta$ and/or IL-10. Specific characteristics of acquired deactivation are shown in Table 2 and, in general, shift the macrophage activation profile to a strong immunosuppressive state.

\section{Uptake of apoptotic cells}

Suppression of macrophages by exposure to apoptotic cells is a well-described biological phenomenon that is observed during development, during normal cell replacement 
throughout life, and during disease. The binding and ingestion of apoptotic cells by macrophages have been termed nonimmunogenic uptake, in contrast to the uptake of pathogens such as bacteria or yeast that has been termed immunogenic uptake. As noted by Erwig and Henson (2007), this is a misnomer in both cases. While uptake of pathogens via Fc receptors, complement receptors, or lectins results in production of proinflammatory cytokines and can be proinflammatory (i.e., "immunogenic"), pathogen uptake via Fc receptors can also inhibit inflammation (Crocker et al. 2007; Hamerman and Lanier 2006; Long 2008; Underhill and Goodridge 2007; van Lookeren Campagne et al. 2007). Likewise, the term "nonimmunogenic" implies a neutral or static effect on inflammation when, in fact, apoptotic cell uptake strongly downregulates macrophage activity. Active suppression of the innate immune response has both beneficial effects (tissue is preserved from self-damage) and damaging effects (the invading organisms is not controlled) and plays an important role in chronic diseases.

The removal of apoptotic cells in the brain is the primary job of microglia although other cell types, most commonly astrocytes, contribute to clearance (Griffiths et al. 2009). While macrophages express a wide variety of receptors that detect which dying cell is destined for uptake, cells undergoing apoptosis signal loss of viability by a sparse repertoire of mechanisms. As shown in Fig. 2, apoptotic cells are primarily identified by redistribution of phosphatidylserine (PS) to the surface membrane and the appearance of calreticulin (CRT) on the cell surface (Gardai et al. 2005; Gregory and Devitt 2004; Hume 2008; Wu et al. 2006). In some cases, complement component, C1q, binding to membrane blebs on apoptotic cells may also serve as a signal to phagocytes (Maderna and Godson 2003). Microglia and other macrophages express PS receptors that bind directly to PS on the apoptotic cell and initiate phagocytosis. Alternatively, macrophages produce and secrete specialized linker (adaptor) proteins that are also called opsonins. Grommes et al. (2008) have recently described the role of one of the linker proteins, growth arrest specific 6 (GAS-6), in microglial phagocytosis. GAS6 links PS on the apoptotic cell surface with the Axl/Mer family of receptor tyrosine kinases on the microglia, mediating uptake of apoptotic cells. Grommes showed that simply adding GAS-6 to BV2 microglia in culture enhanced binding of microspheres to the microglial membrane and reduced IL- $1 \beta$ and NOS 2 gene induction in LPS-treated cells. Additional proteins such as milk fat globule factor E8 (MFG-E8) may be required for the final phagocytosis step. Fuller and Van Eldik (2008) have shown that dominant negative forms of MFG-E8 block phagocytosis, suggesting an integral role for MFG-E8 in the multistep uptake of apoptotic neurons by microglia. Immunosuppression has also been demonstrated in microglia by Minghetti and Pocchiari (2007) who have shown that exposure of cultured microglia to either apoptotic cells or to phosphotidyl serine-laden liposomes decreased TNF- $\alpha$ and NOS2 mRNA and their gene products. These data demonstrate that the microglial mechanisms for uptake of apoptotic cells are tightly linked to suppression of proinflammatory cytokine induction. Potential mechanisms for this immunosuppression of macrophage function have been reviewed by Birge and Ucker (2008).

\section{TGF- $\beta$ and IL-10 in acquired deactivation}

TGF- $\beta$ and IL-10 are known induction agents for acquired deactivation and are released by multiple cell types in the brain including astrocytes (Fadok et al. 1998; Finch et al. 1993; Pratt and McPherson 1997). Microglia are a major source of brain TGF- $\beta$ and uptake of apoptotic cells increases the production and release of both TGF- $\beta$ and IL-10 by microglia (De Simone et al. 2004; Minghetti et al.
Fig. 2 Acquired deactivation
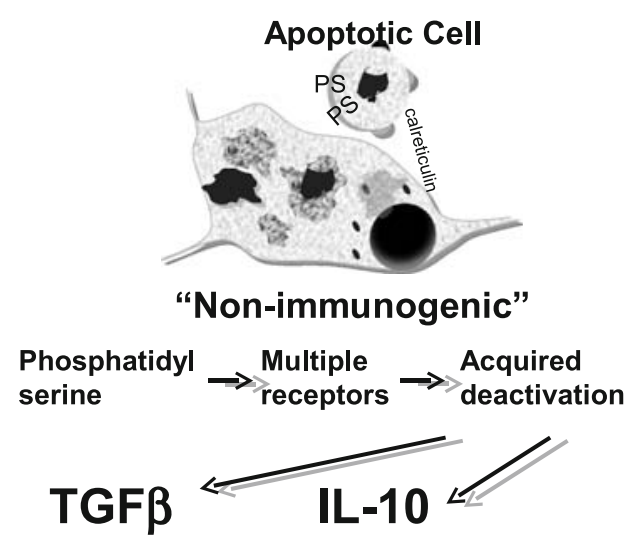

Down regulation of pro-inflammatory cytokine production, including NOS2.

Increased blood brain barrier permeability and tight junction proteins.

Collagen deposition at vasculature.

Increased production of IL-10, TGF $\beta$, NGF, PGE2, other growth factors.

Increased expression of IL-4Ra which synergizes IL-4 and IL-10 activity.

Activation of heme-oxygenase 1 (HO-1) to protect cells.

Activation of sphingosine-1-phosphate via sph kinase which promotes anti-apoptotic pathways in surrounding cells. 
2005). In addition to these anti-inflammatory cytokines, treatment of microglia with apoptotic cells increases mRNA and protein levels for prostaglandin E2, cyclooxygenase 2, and NGF (Minghetti and Pocchiari 2007). Xiao et al. (2008) have further shown in macrophage cell lines that contact with apoptotic cells increases translation and transcription of TGF- $\beta$. Both TGF- $\beta$ and IL-10 inhibit immune-stimulated IL-1 $\beta$, IL- 6 , IL-12, IL-18, and TNF- $\alpha$ production, decrease levels of chemokines, and decrease expression of MHC II and its costimulatory proteins (Fadok et al. 1998; Lodge and Sriram 1996; Martinez et al. 2008; Minghetti et al. 2005; Takahashi et al. 2005; Wei and Jonakait 1999). IL-10 and TGF- $\beta$ have growth factor properties and promote survival of neurons or other cells via actions on Bcl2 and Bcl- $\mathrm{X}_{\mathrm{L}}$ (Finch et al. 1993; Kiefer et al. 1995; Vivien and Ali 2006; Weis et al. 2009; Zocchia et al. 1997). Additionally, TGF- $\beta$ and IL-10 both affect the cerebrovasculature by increasing tight junctions at the blood-brain barrier (Oshima et al. 2001; Ronaldson et al. 2009; Wu et al. 2008). In adult mice, TGF- $\beta$ knockout leads to vascular defects and loss of brain-blood barrier integrity (Basu et al. 2002). Makwana et al. (2007) showed that MHCII expression and the number of perivascular microglia significantly increased in TGF- $\beta$-deficient mice. However, the resulting localized proinflammatory state was not associated with increased invasion of circulating granulocytes into the brain, suggesting that despite the accumulation of perivascular microglia, the blood-brain barrier had not broken down.

Although overlapping, the effects of IL-10 and TGF- $\beta$ are not identical. Exposure to IL-10 increases the expression of IL-4R $\alpha$, a receptor variant for IL-4 and IL-13, thus increasing the sensitivity of the macrophage for these alternative activation stimuli (Andrews et al. 2006). As a result, the combination of IL-4 and IL-10 acts synergistically to alter macrophage function. Lang et al. (2002) have shown that arginase $1 \mathrm{mRNA}$ and protein expression by macrophages is increased by IL-4 treatment but dramatically increases more when both IL-10 and IL-4 are present than IL-4 alone. IL-10 also helps to offset the inhibitory effect of LPS on IL-4-mediated induction of arginase 1. IL10 's protective effects are mediated, in part, by heme oxygenase 1 (HO-1; Lee and Chau 2002; Weis et al. 2009). HO-1 catalyzes the degradation of intracellular hemecontaining proteins to produce carbon monoxide and bilirubin/biliverdin. HO-1 activation has been shown to provide strong antiapoptotic actions (Weis et al. 2009). Importantly, the mechanisms by which TGF- $\beta$ and IL-10 achieve immunosuppression are different. Immunosuppression by IL-10 requires STAT3 and macrophages from STAT3-deficient mice fail to respond to IL-10 (Lang et al. 2002) while TGF- $\beta$ signaling is mediated by both Smaddependent and Smad-independent pathways ( $\mathrm{Li}$ et al.
2006). The signaling pathways involved in TGF- $\beta$ mediated immunosuppression have been extensively reviewed by Li et al. (2006) and for IL-10 by Mosser and Zhang (2008).

\section{Apoptotic cell uptake and sphingosine 1 phosphate kinase}

Recently, sphingosine-1-phosphate (S1P) has been implicated as an endogenous switch for acquired deactivation in macrophages (Weigert et al. 2007). Sphingolipids are ubiquitous components of membranes that can be metabolized into three biologically active components, ceramide, sphingosine, and S1P (Maceyka et al. 2002). In most cells, the formation of ceramide or sphingosine by activated sphingomyelinases and their accumulation within the cell is linked to induction of apoptosis. In contrast, when ceramide and sphingosine levels are decreased by the production of $\mathrm{S} 1 \mathrm{P}$, cell growth and survival mechanisms are initiated. The increase in S1P levels is due to increased expression and activity of sphingosine kinase (SphK), the enzyme that catalyzes the phosphorylation of sphingosine at the 1-OH site. Two isoforms of SphK have been found (Sphk1; SphK2) and both are activated by growth factors and cytokines (Maceyka et al. 2002). Mouse macrophages predominantly express SphK2 while human cells express both. Weigert et al. (2007) have shown that S1P released from apoptotic cells initiates acquired deactivation in macrophages. This effect was not observed in SphK knockout mice and was dependent on S1P receptors (Hughes et al. 2008; Weigert et al. 2007). Edwards et al. (2006) have also shown that apoptotic cells can induce SphK production within macrophages and has identified this gene family as a marker for the acquired deactivation state.

\section{Alternative activation and acquired deactivation in neurodegenerative disease}

Immunosuppressive mechanisms are used to facilitate wound resolution and the return to tissue homeostasis in all diseases or in tissue injury. However, abnormal prolongation of the same immunosuppressive and repair mechanisms is also associated with chronic disease. Wynn et al. (2004) have defined chronic inflammation as the coexpression of alternative activation and classical activation. This paradigm is clearly observed in some parasitic or bacterial infections where both alternative activation and acquired deactivation of macrophage function promote the long-term "escape" of persistent parasites or pathogens from immune-mediated killing. Consequently, a low-grade 
low-pathology but chronic infection is maintained (Bogdan 2008; Couper et al. 2008; Raes et al. 2007; Wynn et al. 2004). In parasitic diseases such as schistosomiasis, the balance between classical activation and alternative activation/acquired deactivation states is of "benefit" to host and to parasite. The host benefits from reduced self-tissue damage caused by an exuberant proinflammatory response against the parasite while the downregulated macrophage response allows the parasite to survive within the host.

Similar mechanisms likely occur in chronic neurodegenerative diseases such as $\mathrm{AD}$. In $\mathrm{AD}$, the primary persistent immune stimulus is most likely $A \beta$ peptides, either as monomers, oligomers, and/or fibers. While $A \beta$ may initiate a proinflammatory classical activation state in microglia, binding of $A \beta$ peptides and fibers to microglial receptors associated with alternatively activated states, including SRA, CD36, CD47, integrins, and multiple lectins, may initiate immunosuppression and repair mechanisms. A detailed list of proteins that interact with $A \beta$ has been provided in the excellent review on AD by Bharadwaj et al. (2009). In vivo, microglial responses to $A \beta$ show an interesting complexity that might reflect the heterogenous state of microglial activation. For example, in a two-photon imaging study, Meyer-Luehmann et al. (2008) observed the rapid accumulation of microglia at newly born amyloid plaques. However, plaque size did not change over the time course of study in the presence of microglia. This in vivo finding was confirmed by Bolmont et al. (2008) in mice that coexpress mutated human amyloid precursor protein (APP) and mutated human presenilin 1 (PS-1; also called APP/PS1 mice). While these data do not provide a direct view of microglial function during "activation" in response to a plaque, the data imply that microglia prevent plaque expansion. Also, using APP/PS1 mice, Jimenez et al. (2008) showed that microglia surrounding amyloid plaques in young mice (4-6 months) express some IL- $1 \beta$ immunoreactivity but do not express other typical classical activation markers. Instead, the gene profile reflected alternative activation since immunoreactivity for YM-1 (the mouse homolog for human chitinase 3-like-1) was high. In addition, regional IL-4 mRNA levels increased while IL-4 immunopositive astrocytes were observed in similar locations. Maier et al. (2008) have also shown that complement factor $\mathrm{C} 3$ regulates brain IL-4 brain levels in mice expressing the APPsw (K670N, M671L), IN (V717F) transgene. Collectively, these data confirm our data from APP $\operatorname{Tg} 2576$ mouse brain and autopsied brain samples from humans with $\mathrm{AD}$ where expression levels for genes characteristic of alternative activation were significantly increased in $\mathrm{AD}$ compared to age-matched controls (Colton et al. 2006a). Higher levels were found for arginase 1, chitinase 3-like 1, and chitinase 3-like 2. TNF- $\alpha$ mRNA levels were also increased but IL-1 $\beta$ and NOS2 mRNA levels remained unchanged compared to age-matched normal controls. Mannose receptor increased but did not reach significant values due to the large population variability. (Table 3 provides a "working" list of alternative activation and acquired deactivation genes/proteins and corresponding antibodies that may be of use when studying mouse models of AD.) Interestingly, IL-4 and IL-10 are higher in CSF from humans with prion disease (CreutzfeldJacob) and mice models of prion disease also show elevated mRNA and protein levels for TGF- $\beta$, associated with depressed levels of NOS2 and IL-1 $\beta$ (Cunningham et al. 2002; Perry et al. 2002; Stoeck et al. 2005).

It is not yet known if microglia can simultaneously express receptors or other factors associated with different activation states or if distinct microglial populations express only alternative or only classical activation gene profiles. Clearly, different types of pathogen-recognition receptors including TLRs, NODs, and dectin 1 are coexpressed by macrophages. When activated during an immune response, these receptors work in an additive or synergistic manner to upregulate classical activation (Underhill 2007). We also do not know if microglial activation states are functionally plastic. Once polarized to a specific state, can polarized microglia respond in an appropriate manner to a new incoming signal or to the same signal, repeated? To answer these questions, Gratchev et al. (2006) polarized human monocyte-derived macrophages to a classically activated state and then switched the polarization to alternative activation by treatment with IL-4. While the qualitative ability to respond to the new alternative activation signal was preserved, the quantitative response, at least in vitro, was reduced. These interesting studies suggest that repeated signaling or changed signaling during chronic neurodegeneration may produce as yet unknown downregulatory events. Age also affects microglial polarization and function (Conde and Streit 2006). Jimenez et al. (2008) have shown that microglia from 18-month-old APP/PS1 mice increased expression of TNF- $\alpha$ mRNA and protein (classical activation) while IL-4 and Ym-1 expression (alternative activation) decreased compared to young mice. Levels of phagocytic receptors (CD36, SRA, and RAGE) were also decreased in old APP/PS1 mice. Finally, microglial immune polarization may vary by brain region during chronic neuroinflammation. Astrocytes and microglia around brain blood vessels display unique characteristics compared to microglia found in the brain parenchyma. For example, MR and CD163 proteins are upregulated in perivascular microglia, suggesting alternative activation (Galea et al. 2005).

The simultaneous presence of multiple immune activation states in the brain during $\mathrm{AD}$ is consistent with chronic inflammation and with $A \beta$ peptides as a persistent immune stimulus. Using chronic inflammation associated with 
Table 3 Genes and antibodies used for profiling of alternative activation and acquired deactivation

\begin{tabular}{|c|c|c|c|}
\hline $\begin{array}{l}\text { Mouse } \\
\text { gene }\end{array}$ & RefSeq & Mouse antigen & Antibody \\
\hline $\operatorname{Arg} 1$ & NM_007482 & Arginase 1 (A1, Arg1, liver arginase) & $\begin{array}{l}\text { WB-Imgenex (IMG30305); IHC-BD Biosystems } \\
\text { (\#610709) }\end{array}$ \\
\hline Arg2 & NM_009705 & Arginase 2 (A2, Arg2) & WB-AbCam (ab21776) \\
\hline $\mathrm{Cd} 163$ & NM_053094 & Hemoglobin scavenger receptor & $\begin{array}{l}\text { WB, IHC-Human only AbCam (ab17051); WB, IF-Santa } \\
\text { Cruz Biotechnology (sc-18796) }\end{array}$ \\
\hline $\mathrm{Cd} 209 \mathrm{a}$ & NM_133238 & $\begin{array}{l}\text { DC-SIGN (dendritic cell-specific intracellular ad- } \\
\text { hesion molecule 3-grabbing integrin; SIGN-R1- } \\
\text { murine homolog) }\end{array}$ & $\begin{array}{l}\text { WB-E-Biosciences (clone 5H-10, 14-2091); WB, IHC- } \\
\text { AbD Serotec (clone ER-TR9, MCA2394) }\end{array}$ \\
\hline Chi313 & NM_009892 & Ym1 (Chitinase-3-Like-3) & WB-Stem Cell Technologies (\#01404) \\
\hline Chia & NM_023186 & AMCase (acidic mammalian chitinase family) & WB; IF-Santa Cruz Biotechnology (\#sc49355) \\
\hline CLEC7a & NM_020008 & Dectin-1 (C-type lectin domain family 7, member a) & $\begin{array}{l}\text { WB-Santa Cruz Biotechnology (clone 15Y9, sc-73897); } \\
\text { AbD Serotec (MCA2289T); IF-Cell Sciences (clone } \\
\text { 2A11 HM1067) }\end{array}$ \\
\hline IL1RN & NM_031167 & IL-1 receptor antagonist & WB, ELISA-R\&D Systems (AF 480NA) \\
\hline Il4ra & NM_001008700 & Interleukin 4 receptor alpha (CD124) & WB, ELISA-R\&D Systems (clone 129801, mab530) \\
\hline IL12p40 & NM_008352 & Interleukin $12 \mathrm{p} 40$ & $\begin{array}{l}\text { WB, IF, ELISA, IHC-AbD Serotec (clone C15.6, } \\
\text { MCA4689) }\end{array}$ \\
\hline Marco & NM_010766 & $\begin{array}{l}\text { Macrophage receptor with collagenous structure } \\
\text { (MARCO) }\end{array}$ & ICH, IF-AbD Serotec (clone ED31, MCA1849) \\
\hline Mrc1 & Nm_008625 & Mannose receptor (MR; CD206; MMR; CLEC13D) & $\begin{array}{l}\text { WB, IHC-AbD Serotec (MR5D3, MCA2235); WB,IHC- } \\
\text { AbCam (clone 15-2, ab8918) }\end{array}$ \\
\hline Nos2 & NM_010927 & Inducible nitric oxide synthase & $\begin{array}{l}\text { WB, IHC-BD Biosystems (Clone 54, 610600); WB, IHC- } \\
\text { R\&D Systems (clone 2D2-B2, mab9502) }\end{array}$ \\
\hline Retnia & NM_020509 & $\begin{array}{l}\text { Found in inflammatory zone } 1 \text { (FIZZ1) or resistin- } \\
\text { like molecule A (RelmA) }\end{array}$ & WB, IHC-AbCam (ab39626) \\
\hline Sphk2 & NM_203280 & Sphingosine kinase $1 / 2$ & $\begin{array}{l}\text { WB,IHC-ExAlpha (Phospho sphk1 X1882P); WB, IHC- } \\
\text { AbCam (Ab71700) }\end{array}$ \\
\hline $\mathrm{CD} 36$ & NM_007643 & $\begin{array}{l}\text { Thrombospondin receptor; type B scavenger } \\
\text { receptor }\end{array}$ & $\begin{array}{l}\text { WB, AbCam (ab36977) WB, IF- Santa Cruz Biotech- } \\
\text { nology (clone H-300, sc-9154) }\end{array}$ \\
\hline
\end{tabular}

WB Western blot, IHC immunohistochemistry, IF immunofluorescence

parasitic infections as an analogy, polarization of microglial function to alternative activation in $\mathrm{AD}$ may facilitate amyloid deposits while fostering protection of the surrounding tissue from immune damage. Conversely, classical activation may be associated with removal of $A \beta$. Herber et al. (2007) have recently shown that injection of LPS into brains of APP Tg2576 mice resulted in clearance of A $\beta$ from the brain. Cotreatment with LPS and dexamethasoneto block classical activation - prevented A $\beta$ removal. Similar to schistosomiasis, these data strongly suggest that some level of classical activation may be required to limit the brain levels of $\mathrm{A} \beta$, despite the risk of self-tissue damage including neuronal death.

While demonstrating neuroinflammatory profiles reminiscent of humans with $\mathrm{AD}$, mouse models of $\mathrm{AD}$ show minimal neuronal loss even when levels of toxic $A \beta$ species are high (Lesne et al. 2006; Jimenez et al. 2008; Radde et al. 2008). This puzzling observation suggests that immune-mediated damage in amyloid-mediated chronic neuroinflammation in mice is different from humans with
$\mathrm{AD}$ where neuronal damage is prominent and/or that factors other than inflammation contribute to disease progression from amyloid to tau pathology and to neuronal loss. Our laboratory has now shown that disease progression in the presence of $A \beta$ peptides can be achieved by altering a component of the immune environment in mice. We have generated two different mouse models that express mutated human APP on a mouse NOS2 knockout background, thus altering integrated NO levels in these mice. The resultant phenotype is highly reminiscent of AD including (1) parenchymal and cerebrovascular amyloid deposits, (2) hyperphosphorylated and aggregated normal mouse tau in the somatodendritic neuronal compartment, (3) neurodegeneration and significant neuronal loss, including loss of interneurons, and (4) robust cognitive deficits (Colton et al. 2006b; Wilcock et al. 2008). These pathologies are not seen in $\mathrm{NOS}_{2}^{-/}$or APP alone, rather, it is the combination of both that creates the AD-like pathological changes. Suppression of NOS2 is also observed in alternative activation and in acquired deactivation, both of which are found in 
AD. Furthermore, induction of NOS2 shows strong speciesspecific differences. Significant differences in the gene promoter in human NOS2 compared to mouse NOS2 result in the production of different NO levels by human microglia or peripheral macrophages compared to rodents (Colton et al. 1996; Ganster et al. 2001; Mestas and Hughes 2004; Snell et al. 1997; Weinberg et al. 1995).

How reduced levels of $N O$ synergize with $A \beta$ to promote disease progression in these models is currently unknown, but the effect is likely to include nonimmune actions of NO. The role of NO in pathogen "killing" has been well described. Less appreciated, however, are the complex and critical roles of NO in cell signaling, cell survival, and regulation of redox processes. One of the primary functions of NO in any tissue is to serve as an antioxidant (Ridnour et al. 2004; Wink et al. 1993, 2001). Reduction in the integrated tissue levels of NO by lack of NO production, by increased scavenging of $\mathrm{NO}$, or by chemical interactions of NO with cellular constituents promotes prooxidative conditions. Thomas et al. (2008) have provided an elegant study using cultured cells that clearly demonstrates this concept. Oxidative stress is one of the immutable features of $\mathrm{AD}$ and while the exact sources of oxidizing radicals are controversial, they are likely to include activation of the NADPH oxidase (NOX2; gp91 ${ }^{\text {phox }}$, also known as the respiratory burst oxidase) and iron- or copper-mediated Fenton chemistry generated by the abundant redox active metals in AD brain compared to normal individuals. Our laboratory and others showed a number of years ago that $A \beta$ treatment of microglia increased superoxide anion production (Colton et al. 2000; Van Muiswinkel et al. 1996). Recently, Wilkinson et al. (2006) have shown that $A \beta$ interaction with microglial membranes is mediated by CD36, CD47, and $\alpha 6 \beta 1$ integrin. Formation of the crosslinked receptor complex on the membrane initiates a signaling pathway resulting in the production of superoxide anion by the NADPH oxidase. Furthermore, Shimohama et al. (2000) have shown that NADPH oxidase expression is upregulated in $\mathrm{AD}$ brain. Thus, as suggested by the APPSw $/ \mathrm{NOS}^{-1-}$ and the APPSwDI/NOS2 $2^{--}$mice, altered levels of NO produced by genetic removal of NOS2, by chronic immunosuppression and by high levels of NO scavengers may facilitate a shift in redox state to favor oxidative stress and to promote $\mathrm{AD}$-like disease progression in mice.

In summary, chronic neuroinflammation clearly differs from acute inflammation in the brain and studies that focus on short-term assessment of the proinflammatory status of the innate immune response may provide only a partial view of the impact of immune activity on brain function as it relates to chronic diseases. The combination of alternative activation states with classical activation states more closely mimics the complexity of persistent chronic disease and suggests an uneasy balance between the opposite poles of proinflammation and increased self-toxicity and anti-inflammation and longer tissue survival but with maintained infection. Ideally, understanding how to shift these states to promote successful repair and the return to tissue homeostasis while ridding the brain of the immune stimulus is a major goal of successful treatment of neurodegenerative diseases.

Conflict of interest The author has no conflict of interest.

Open Access This article is distributed under the terms of the Creative Commons Attribution Noncommercial License which permits any noncommercial use, distribution, and reproduction in any medium, provided the original author(s) and source are credited.

\section{References}

Abbas N, Bednar I, Mix E, Marie S, Paterson D, Ljungberg A, Morris C, Winblad B, Nordberg A, Zhu J (2002) Up-regulation of the inflammatory cytokines IFN-gamma and IL-12 and downregulation of IL-4 in cerebral cortex regions of APP(SWE) transgenic mice. J Neuroimmunol 126:50-57

Abbott NJ (2004) Evidence for bulk flow of brain interstitial fluid: significance for physiology and pathology. Neurochem Int 45:545552

Abbott NJ, Ronnback L, Hansson E (2006) Astrocyte-endothelial interactions at the blood-brain barrier. Nat Rev Neurosci 7:41-53

Adams DO, Hamilton TA (1987) Molecular transductional mechanisms by which IFN gamma and other signals regulate macrophage development. Immunol Rev 97:5-27

Ajami B, Bennett JL, Krieger C, Tetzlaff W, Rossi FM (2007) Local self-renewal can sustain CNS microglia maintenance and function throughout adult life. Nat Neurosci 10:1538-1543

Andrews AL, Holloway JW, Holgate ST, Davies DE (2006) IL-4 receptor alpha is an important modulator of IL-4 and IL-13 receptor binding: implications for the development of therapeutic targets. J Immunol 176:7456-7461

Atochina O, Da'dara AA, Walker M, Harn DA (2008) The immunomodulatory glycan LNFPIII initiates alternative activation of murine macrophages in vivo. Immunology 125:111-121

Baetz A, Frey M, Heeg K, Dalpke AH (2004) Suppressor of cytokine signaling (SOCS) proteins indirectly regulate toll-like receptor signaling in innate immune cells. J Biol Chem 279:54708-54715

Basu A, Krady JK, Enterline JR, Levison SW (2002) Transforming growth factor beta1 prevents IL-1beta-induced microglial activation, whereas TNF alpha- and IL-6-stimulated activation are not antagonized. Glia 40:109-120

Bharadwaj PR, Dubey AK, Masters CL, Martins RN, Macreadie IG (2009) Abeta aggregation and possible implications in Alzheimer's disease pathogenesis. J Cell Mol Med 13(3):412-421

Birge RB, Ucker DS (2008) Innate apoptotic immunity: the calming touch of death. Cell Death Differ 15:1096-1102

Bogdan C (2008) Mechanisms and consequences of persistence of intracellular pathogens: leishmaniasis as an example. Cell Microbiol 10:1221-1234

Bogdan C, Vodovotz Y, Nathan C (1991) Macrophage deactivation by interleukin 10. J Exp Med 174:1549-1555

Bolmont T, Haiss F, Eicke D, Radde R, Mathis CA, Klunk WE, Kohsaka S, Jucker M, Calhoun ME (2008) Dynamics of the 
microglial/amyloid interaction indicate a role in plaque maintenance. J Neurosci 28:4283-4292

Boulton M, Young A, Hay J, Armstrong D, Flessner M, Schwartz M, Johnston M (1996) Drainage of CSF through lymphatic pathways and arachnoid villi in sheep: measurement of 125I-albumin clearance. Neuropathol Appl Neurobiol 22:325-333

Boulton M, Flessner M, Armstrong D, Hay J, Johnston M (1998) Determination of volumetric cerebrospinal fluid absorption into extracranial lymphatics in sheep. Am J Physiol 274:R88-R96

Braissant O, Gotoh T, Loup M, Mori M, Bachmann C (1999) L-arginine uptake, the citrulline-NO cycle and arginase II in the rat brain: an in situ hybridization study. Brain Res Mol Brain Res 70:231-241

Brodie C, Goldreich N, Haiman T, Kazimirsky G (1998) Functional IL-4 receptors on mouse astrocytes: IL-4 inhibits astrocyte activation and induces NGF secretion. J Neuroimmunol 81:20-30

Buga GM, Singh R, Pervin S, Rogers NE, Schmitz DA, Jenkinson CP, Cederbaum SD, Ignarro LJ (1996) Arginase activity in endothelial cells: inhibition by NG-hydroxy-L-arginine during highoutput NO production. Am J Physiol 271:H1988-H1998

Busch SA, Silver J (2007) The role of extracellular matrix in CNS regeneration. Curr Opin Neurobiol 17:120-127

Carare RO, Bernardes-Silva M, Newman TA, Page AM, Nicoll JA, Perry VH, Weller RO (2008) Solutes, but not cells, drain from the brain parenchyma along basement membranes of capillaries and arteries: significance for cerebral amyloid angiopathy and neuroimmunology. Neuropathol Appl Neurobiol 34:131-144

Castellani RJ, Siedlak SL, Fortino AE, Perry G, Ghetti B, Smith MA (2005) Chitin-like polysaccharides in Alzheimer's disease brains. Curr Alzheimer Res 2:419-423

Cederbaum SD, Yu H, Grody WW, Kern RM, Yoo P, Iyer RK (2004) Arginases I and II: do their functions overlap? Mol Genet Metab 81(Suppl 1):S38-S44

Chieppa M, Bianchi G, Doni A, Del Prete A, Sironi M, Laskarin G, Monti P, Piemonti L, Biondi A, Mantovani A, Introna $\mathrm{M}$, Allavena P (2003) Cross-linking of the mannose receptor on monocyte-derived dendritic cells activates an anti-inflammatory immunosuppressive program. J Immunol 171:4552-4560

Chuang TH, Ulevitch RJ (2004) Triad3A, an E3 ubiquitin-protein ligase regulating Toll-like receptors. Nat Immunol 5:495-502

Closs EI, Boissel JP, Habermeier A, Rotmann A (2006) Structure and function of cationic amino acid transporters (CATs). J Membr Biol 213:67-77

Colton C, Wilt S, Gilbert D, Chernyshev O, Snell J, Dubois-Dalcq M (1996) Species differences in the generation of reactive oxygen species by microglia. Mol Chem Neuropathol 28:15-20

Colton CA, Chernyshev ON, Gilbert DL, Vitek MP (2000) Microglial contribution to oxidative stress in Alzheimer's disease. Ann N Y Acad Sci 899:292-307

Colton CA, Mott RT, Sharpe H, Xu Q, Van Nostrand WE, Vitek MP (2006a) Expression profiles for macrophage alternative activation genes in $\mathrm{AD}$ and in mouse models of $\mathrm{AD}$. J Neuroinflammation 3:27

Colton CA, Vitek MP, Wink DA, Xu Q, Cantillana V, Previti ML, Van Nostrand WE, Weinberg JB, Dawson H (2006b) NO synthase 2 (NOS2) deletion promotes multiple pathologies in a mouse model of Alzheimer's disease. Proc Natl Acad Sci U S A 103:12867-12872

Conde JR, Streit WJ (2006) Microglia in the aging brain. J Neuropathol Exp Neurol 65:199-203

Couper KN, Blount DG, Riley EM (2008) IL-10: the master regulator of immunity to infection. J Immunol 180:5771-5777

Crocker PR, Paulson JC, Varki A (2007) Siglecs and their roles in the immune system. Nat Rev Immunol 7:255-266

Cunningham C, Boche D, Perry VH (2002) Transforming growth factor beta1, the dominant cytokine in murine prion disease: influence on inflammatory cytokine synthesis and alteration of vascular extracellular matrix. Neuropathol Appl Neurobiol 28:107-119

Czapiga M, Colton CA (2003) Microglial function in human APOE3 and APOE4 transgenic mice: altered arginine transport. J Neuroimmunol 134:44-51

De Simone R, Ajmone-Cat MA, Minghetti L (2004) Atypical antiinflammatory activation of microglia induced by apoptotic neurons: possible role of phosphatidylserine-phosphatidylserine receptor interaction. Mol Neurobiol 29:197-212

Denker SP, Ji S, Dingman A, Lee SY, Derugin N, Wendland MF, Vexler ZS (2007) Macrophages are comprised of resident brain microglia not infiltrating peripheral monocytes acutely after neonatal stroke. J Neurochem 100:893-904

Durante W, Liao L, Reyna SV, Peyton KJ, Schafer AI (2001) Transforming growth factor-beta(1) stimulates L-arginine transport and metabolism in vascular smooth muscle cells: role in polyamine and collagen synthesis. Circulation 103:1121-1127

Ebert S, Schoeberl T, Walczak Y, Stoecker K, Stempfl T, Moehle C, Weber BH, Langmann T (2008) Chondroitin sulfate disaccharide stimulates microglia to adopt a novel regulatory phenotype. J Leukoc Biol 84:736-740

Edwards JP, Zhang X, Frauwirth KA, Mosser DM (2006) Biochemical and functional characterization of three activated macrophage populations. J Leukoc Biol 80:1298-1307

Erwig LP, Henson PM (2007) Immunological consequences of apoptotic cell phagocytosis. Am J Pathol 171:2-8

Fabriek BO, Dijkstra CD, van den Berg TK (2005) The macrophage scavenger receptor CD163. Immunobiology 210:153-160

Fadok VA, Bratton DL, Konowal A, Freed PW, Westcott JY, Henson PM (1998) Macrophages that have ingested apoptotic cells in vitro inhibit proinflammatory cytokine production through autocrine/ paracrine mechanisms involving TGF-beta, PGE2, and PAF. J Clin Invest 101:890-898

Finch CE, Laping NJ, Morgan TE, Nichols NR, Pasinetti GM (1993) TGF-beta 1 is an organizer of responses to neurodegeneration. J Cell Biochem 53:314-322

Ford JW, Kilmon MA, Haas KM, Shelburne AE, Chan-Li Y, Conrad DH (2006) In vivo murine CD23 destabilization enhances CD23 shedding and IgE synthesis. Cell Immunol 243:107-117

Freire-de-Lima CG, Xiao YQ, Gardai SJ, Bratton DL, Schiemann WP, Henson PM (2006) Apoptotic cells, through transforming growth factor-beta, coordinately induce anti-inflammatory and suppress pro-inflammatory eicosanoid and NO synthesis in murine macrophages. J Biol Chem 281:38376-38384

Fuller AD, Van Eldik L (2008) MFG-E8 regulates microglial phagocytosis of apoptotic neurons. J Neuroimmune Pharmacol 3:246-256

Galea I, Palin K, Newman TA, Van Rooijen N, Perry VH, Boche D (2005) Mannose receptor expression specifically reveals perivascular macrophages in normal, injured, and diseased mouse brain. Glia 49:375-384

Galtrey CM, Fawcett JW (2007) The role of chondroitin sulfate proteoglycans in regeneration and plasticity in the central nervous system. Brain Res Rev 54:1-18

Ganster RW, Taylor BS, Shao L, Geller DA (2001) Complex regulation of human inducible nitric oxide synthase gene transcription by Stat 1 and NF-kappa B. Proc Natl Acad Sci U S A 98:8638-8643

Gardai SJ, McPhillips KA, Frasch SC, Janssen WJ, Starefeldt A, Murphy-Ullrich JE, Bratton DL, Oldenborg PA, Michalak M, Henson PM (2005) Cell-surface calreticulin initiates clearance of viable or apoptotic cells through trans-activation of LRP on the phagocyte. Cell 123:321-334

Garlind A, Brauner A, Hojeberg B, Basun H, Schultzberg M (1999) Soluble interleukin-1 receptor type II levels are elevated in cerebrospinal fluid in Alzheimer's disease patients. Brain Res 826:112-116 
Glezer I, Simard AR, Rivest S (2007) Neuroprotective role of the innate immune system by microglia. Neuroscience 147:867-883

Gordon S (2003) Alternative activation of macrophages. Nat Rev Immunol 3:23-35

Gordon S, Taylor PR (2005) Monocyte and macrophage heterogeneity. Nat Rev Immunol 5:953-964

Gratchev A, Kzhyshkowska J, Utikal J, Goerdt S (2005) Interleukin-4 and dexamethasone counterregulate extracellular matrix remodelling and phagocytosis in type-2 macrophages. Scand J Immunol 61:10-17

Gratchev A, Kzhyshkowska J, Kothe K, Muller-Molinet I, Kannookadan S, Utikal J, Goerdt S (2006) Mphi1 and Mphi2 can be re-polarized by Th2 or Th1 cytokines, respectively, and respond to exogenous danger signals. Immunobiology 211:473-486

Gregory CD, Devitt A (2004) The macrophage and the apoptotic cell: an innate immune interaction viewed simplistically? Immunology 113:1-14

Griffiths MR, Gasque P, Neal JW (2009) The multiple roles of the innate immune system in the regulation of apoptosis and inflammation in the brain. J Neuropathol Exp Neurol 68:217226

Grommes C, Lee CY, Wilkinson BL, Jiang Q, Koenigsknecht-Talboo JL, Varnum B, Landreth GE (2008) Regulation of microglial phagocytosis and inflammatory gene expression by Gas6 acting on the Axl/Mer family of tyrosine kinases. J Neuroimmune Pharmacol 3:130-140

Hamerman JA, Lanier LL (2006) Inhibition of immune responses by ITAM-bearing receptors. Sci STKE 2006:re1

Hamilton TA, Ohmori Y, Tebo JM, Kishore R (1999) Regulation of macrophage gene expression by pro- and anti-inflammatory cytokines. Pathobiology 67:241-244

Han J, Ulevitch RJ (2005) Limiting inflammatory responses during activation of innate immunity. Nat Immunol 6:1198-1205

Herber DL, Mercer M, Roth LM, Symmonds K, Maloney J, Wilson N, Freeman MJ, Morgan D, Gordon MN (2007) Microglial activation is required for Abeta clearance after intracranial injection of lipopolysaccharide in APP transgenic mice. J Neuroimmune Pharmacol 2:222-231

Hughes JE, Srinivasan S, Lynch KR, Proia RL, Ferdek P, Hedrick CC (2008) Sphingosine-1-phosphate induces an anti inflammatory phenotype in macrophages. Circ Res 102:950-958

Hume DA (2008) Bring out your dead. Nat Immunol 9:12-14

Hung SI, Chang AC, Kato I, Chang NC (2002) Transient expression of Ym1, a heparin-binding lectin, during developmental hematopoiesis and inflammation. J Leukoc Biol 72:72-82

Jimenez S, Baglietto-Vargas D, Caballero C, Moreno-Gonzalez I, Torres M, Sanchez-Varo R, Ruano D, Vizuete M, Gutierrez A, Vitorica J (2008) Inflammatory response in the hippocampus of PS1M146L/APP751SL mouse model of Alzheimer's disease: age-dependent switch in the microglial phenotype from alternative to classic. J Neurosci 28:11650-11661

Junker N, Johansen JS, Hansen LT, Lund EL, Kristjansen PE (2005) Regulation of YKL-40 expression during genotoxic or microenvironmental stress in human glioblastoma cells. Cancer Sci 96:183-190

Kariko K, Weissman D, Welsh FA (2004) Inhibition of toll-like receptor and cytokine signaling - a unifying theme in ischemic tolerance. J Cereb Blood Flow Metab 24:1288-1304

Kawakami M, Leland P, Kawakami K, Puri RK (2001) Mutation and functional analysis of IL-13 receptors in human malignant glioma cells. Oncol Res 12:459-467

Kerrigan AM, Brown GD (2009) C-type lectins and phagocytosis. Immunobiology 214:562-575

Kiefer R, Streit WJ, Toyka KV, Kreutzberg GW, Hartung HP (1995) Transforming growth factor-beta 1: a lesion-associated cytokine of the nervous system. Int J Dev Neurosci 13:331-339
Kitamura Y, Taniguchi T, Kimura H, Nomura Y, Gebicke-Haerter PJ (2000) Interleukin-4-inhibited mRNA expression in mixed rat glial and in isolated microglial cultures. J Neuroimmunol 106:95-104

Kuhn PH, Marjaux E, Imhof A, De Strooper B, Haass C, Lichtenthaler SF (2007) Regulated intramembrane proteolysis of the interleukin-1 receptor II by alpha-, beta-, and gamma-secretase. J Biol Chem 282:11982-11995

Lang R, Patel D, Morris JJ, Rutschman RL, Murray PJ (2002) Shaping gene expression in activated and resting primary macrophages by IL-10. J Immunol 169:2253-2263

Ledeboer A, Breve JJ, Poole S, Tilders FJ, Van Dam AM (2000) Interleukin-10, interleukin-4, and transforming growth factorbeta differentially regulate lipopolysaccharide-induced production of pro-inflammatory cytokines and nitric oxide in co-cultures of rat astroglial and microglial cells. Glia 30:134-142

Lee TS, Chau LY (2002) Heme oxygenase-1 mediates the antiinflammatory effect of interleukin-10 in mice. Nat Med 8:240 246

Lee YB, Nagai A, Kim SU (2002) Cytokines, chemokines, and cytokine receptors in human microglia. J Neurosci Res 69:94-103

Leidi M, Gotti E, Bologna L, Miranda E, Rimoldi M, Sica A, Roncalli M, Palumbo GA, Introna M, Golay J (2009) M2 macrophages phagocytose rituximab-opsonized leukemic targets more efficiently than $\mathrm{m} 1$ cells in vitro. J Immunol 182:4415-4422

Lesne S, Koh MT, Kotilinek L, Kayed R, Glabe CG, Yang A, Gallagher M, Ashe KH (2006) A specific amyloid-beta protein assembly in the brain impairs memory. Nature 440:352-357

Li MO, Wan YY, Sanjabi S, Robertson AK, Flavell RA (2006) Transforming growth factor-beta regulation of immune responses. Annu Rev Immunol 24:99-146

Linehan SA, Martinez-Pomares L, Stahl PD, Gordon S (1999) Mannose receptor and its putative ligands in normal murine lymphoid and nonlymphoid organs: in situ expression of mannose receptor by selected macrophages, endothelial cells, perivascular microglia, and mesangial cells, but not dendritic cells. J Exp Med 189:1961-1972

Linehan SA, Coulson PS, Wilson RA, Mountford AP, Brombacher F, Martinez-Pomares L, Gordon S (2003) IL-4 receptor signaling is required for mannose receptor expression by macrophages recruited to granulomata but not resident cells in mice infected with Schistosoma mansoni. Lab Invest 83:1223-1231

Liu J, Hatzoglou M (1998) Control of expression of the gene for the arginine transporter Cat-1 in rat liver cells by glucocorticoids and insulin. Amino Acids 15:321-337

Liu T, Dhanasekaran SM, Jin H, Hu B, Tomlins SA, Chinnaiyan AM, Phan SH (2004) FIZZ1 stimulation of myofibroblast differentiation. Am J Pathol 164:1315-1326

Lodge PA, Sriram S (1996) Regulation of microglial activation by TGF-beta, IL-10, and CSF-1. J Leukoc Biol 60:502-508

Long EO (2008) Negative signaling by inhibitory receptors: the NK cell paradigm. Immunol Rev 224:70-84

Lyons A, Griffin RJ, Costelloe CE, Clarke RM, Lynch MA (2007a) IL-4 attenuates the neuroinflammation induced by amyloid-beta in vivo and in vitro. $J$ Neurochem 101:771-781

Lyons A, Downer EJ, Crotty S, Nolan YM, Mills KH, Lynch MA (2007b) CD200 ligand receptor interaction modulates microglial activation in vivo and in vitro: a role for IL-4. J Neurosci 27:8309-8313

Maceyka M, Payne SG, Milstien S, Spiegel S (2002) Sphingosine kinase, sphingosine-1-phosphate, and apoptosis. Biochim Biophys Acta 1585:193-201

Maderna P, Godson C (2003) Phagocytosis of apoptotic cells and the resolution of inflammation. Biochim Biophys Acta 1639:141-151

Maier M, Peng Y, Jiang L, Seabrook TJ, Carroll MC, Lemere CA (2008) Complement C3 deficiency leads to accelerated amyloid beta plaque deposition and neurodegeneration and modulation of 
the microglia/macrophage phenotype in amyloid precursor protein transgenic mice. J Neurosci 28:6333-6341

Makwana M, Jones LL, Cuthill D, Heuer H, Bohatschek M, Hristova M, Friedrichsen S, Ormsby I, Bueringer D, Koppius A, Bauer K, Doetschman T, Raivich G (2007) Endogenous transforming growth factor beta 1 suppresses inflammation and promotes survival in adult CNS. J Neurosci 27:11201-11213

Malaterre J, Strambi C, Aouane A, Strambi A, Rougon G, Cayre M (2004) A novel role for polyamines in adult neurogenesis in rodent brain. Eur J NeuroSci 20:317-330

Manner CK, Nicholson B, MacLeod CL (2003) CAT2 arginine transporter deficiency significantly reduces iNOS-mediated NO production in astrocytes. J Neurochem 85:476-482

Mantovani A, Sozzani S, Locati M, Allavena P, Sica A (2002) Macrophage polarization: tumor-associated macrophages as a paradigm for polarized M2 mononuclear phagocytes. Trends Immunol 23:549-555

Marletta MA (1994) Nitric oxide synthase: aspects concerning structure and catalysis. Cell 78:927-930

Martinez FO, Sica A, Mantovani A, Locati M (2008) Macrophage activation and polarization. Front Biosci 13:453-461

Mestas J, Hughes CC (2004) Of mice and not men: differences between mouse and human immunology. J Immunol 172:2731-2738

Meyer-Luehmann M, Spires-Jones TL, Prada C, Garcia-Alloza M, de Calignon A, Rozkalne A, Koenigsknecht-Talboo J, Holtzman DM, Bacskai BJ, Hyman BT (2008) Rapid appearance and local toxicity of amyloid-beta plaques in a mouse model of Alzheimer's disease. Nature 451:720-724

Mildner A, Schmidt H, Nitsche M, Merkler D, Hanisch UK, Mack M, Heikenwalder M, Bruck W, Priller J, Prinz M (2007) Microglia in the adult brain arise from Ly-6ChiCCR2+ monocytes only under defined host conditions. Nat Neurosci 10:1544-1553

Mills CD, Kincaid K, Alt JM, Heilman MJ, Hill AM (2000) M-1/M-2 macrophages and the Th1/Th2 paradigm. J Immunol 164:6166-6173

Minghetti L, Pocchiari M (2007) Cyclooxygenase-2, prostaglandin E2, and microglial activation in prion diseases. Int Rev Neurobiol $82: 265-275$

Minghetti L, Ajmone-Cat MA, De Berardinis MA, De Simone R (2005) Microglial activation in chronic neurodegenerative diseases: roles of apoptotic neurons and chronic stimulation. Brain Res Brain Res Rev 48:251-256

Moncada S, Higgs EA (1991) Endogenous nitric oxide: physiology, pathology and clinical relevance. Eur J Clin Invest 21:361374

Morgan TE, Nichols NR, Pasinetti GM, Finch CE (1993) TGF-beta 1 mRNA increases in macrophage/microglial cells of the hippocampus in response to deafferentation and kainic acid-induced neurodegeneration. Exp Neurol 120:291-301

Morris SM Jr (2004a) Recent advances in arginine metabolism. Curr Opin Clin Nutr Metab Care 7:45-51

Morris SM Jr (2004b) Enzymes of arginine metabolism. J Nutr 134:2743S-2747S discussion 2765S-2767S

Morris SM Jr (2007) Arginine metabolism: boundaries of our knowledge. J Nutr 137:1602S-1609S

Morris SM Jr, Kepka-Lenhart D, Chen LC (1998) Differential regulation of arginases and inducible nitric oxide synthase in murine macrophage cells. Am J Physiol 275:E740-E747

Morwood SR, Nicholson LB (2006) Modulation of the immune response by extracellular matrix proteins. Arch Immunol Ther Exp (Warsz) 54:367-374

Mosser DM (2003) The many faces of macrophage activation. J Leukoc Biol 73:209-212

Mosser DM, Zhang X (2008) Interleukin-10: new perspectives on an old cytokine. Immunol Rev 226:205-218

Nimmerjahn F, Ravetch JV (2006) Fcgamma receptors: old friends and new family members. Immunity 24:19-28
Noel W, Raes G, Hassanzadeh Ghassabeh G, De Baetselier P, Beschin A (2004) Alternatively activated macrophages during parasite infections. Trends Parasitol 20:126-133

O'Connell RM, Taganov KD, Boldin MP, Cheng G, Baltimore D (2007) MicroRNA-155 is induced during the macrophage inflammatory response. Proc Natl Acad Sci U S A 104:1604-1609

Odegaard JI, Ricardo-Gonzalez RR, Goforth MH, Morel CR, Subramanian V, Mukundan L, Eagle AR, Vats D, Brombacher F, Ferrante AW, Chawla A (2007) Macrophage-specific PPARgamma controls alternative activation and improves insulin resistance. Nature 447:1116-1120

Ogawa R, Pacelli R, Espey MG, Miranda KM, Friedman N, Kim SM, Cox G, Mitchell JB, Wink DA, Russo A (2001) Comparison of control of Listeria by nitric oxide redox chemistry from murine macrophages and NO donors: insights into listeriocidal activity of oxidative and nitrosative stress. Free Radic Biol Med 30:268-276

Oshima T, Laroux FS, Coe LL, Morise Z, Kawachi S, Bauer P, Grisham MB, Specian RD, Carter P, Jennings S, Granger DN, Joh T, Alexander JS (2001) Interferon-gamma and interleukin-10 reciprocally regulate endothelial junction integrity and barrier function. Microvasc Res 61:130-143

Pachter JS, de Vries HE, Fabry Z (2003) The blood-brain barrier and its role in immune privilege in the central nervous system. J Neuropathol Exp Neurol 62:593-604

Perry VH, Gordon S (1988) Macrophages and microglia in the nervous system. Trends Neurosci 11:273-277

Perry VH, Cunningham C, Boche D (2002) Atypical inflammation in the central nervous system in prion disease. Curr Opin Neurol 15:349-354

Perry VH, Cunningham C, Holmes C (2007) Systemic infections and inflammation affect chronic neurodegeneration. Nat Rev Immunol 7:161-167

Pfitzner E, Kliem S, Baus D, Litterst CM (2004) The role of STATs in inflammation and inflammatory diseases. Curr Pharm Des 10:2839-2850

Ponomarev ED, Maresz K, Tan Y, Dittel BN (2007) CNS-derived interleukin-4 is essential for the regulation of autoimmune inflammation and induces a state of alternative activation in microglial cells. J Neurosci 27:10714-10721

Pousset F, Cremona S, Dantzer R, Kelley KW, Parnet P (2001) IL-10 and IL-4 regulate type-I and type-II IL-1 receptors expression on IL-1 beta-activated mouse primary astrocytes. J Neurochem 79:726-736

Pratt BM, McPherson JM (1997) TGF-beta in the central nervous system: potential roles in ischemic injury and neurodegenerative diseases. Cytokine Growth Factor Rev 8:267-292

Radde R, Duma C, Goedert M, Jucker M (2008) The value of incomplete mouse models of Alzheimer's disease. Eur J Nucl Med Mol Imaging 35(Suppl 1):S70-S74

Raes G, Beschin A, Ghassabeh GH, De Baetselier P (2007) Alternatively activated macrophages in protozoan infections. Curr Opin Immunol 19:454-459

Raes G, De Baetselier P, Noel W, Beschin A, Brombacher F, Hassanzadeh Gh G (2002a) Differential expression of FIZZ1 and $\mathrm{Ym} 1$ in alternatively versus classically activated macrophages. J Leukoc Biol 71:597-602

Raes G, Noel W, Beschin A, Brys L, de Baetselier P, Hassanzadeh GH (2002b) FIZZ1 and Ym as tools to discriminate between differentially activated macrophages. Dev Immunol 9:151-159

Raes G, Brys L, Dahal BK, Brandt J, Grooten J, Brombacher F, Vanham G, Noel W, Bogaert P, Boonefaes T, Kindt A, Van den Bergh R, Leenen PJ, De Baetselier P, Ghassabeh GH (2005) Macrophage galactose-type C-type lectins as novel markers for alternatively activated macrophages elicited by parasitic infections and allergic airway inflammation. J Leukoc Biol 77:321327 
Rajpathak SN, Gunter MJ, Wylie-Rosett J, Ho GY, Kaplan RC, Muzumdar R, Rohan TE, Strickler HD (2009) The role of insulinlike growth factor-I and its binding proteins in glucose homeostasis and type 2 diabetes. Diabetes Metab Res Rev 25:3-12

Reboldi A, Coisne C, Baumjohann D, Benvenuto F, Bottinelli D, Lira S, Uccelli A, Lanzavecchia A, Engelhardt B, Sallusto F (2009) C-C chemokine receptor 6-regulated entry of TH-17 cells into the CNS through the choroid plexus is required for the initiation of EAE. Nat Immunol 10:514-523

Recklies AD, White C, Ling H (2002) The chitinase 3-like protein human cartilage glycoprotein 39 (HC-gp39) stimulates proliferation of human connective-tissue cells and activates both extracellular signal-regulated kinase- and protein kinase B-mediated signalling pathways. Biochem J 365:119-126

Reese TA, Liang HE, Tager AM, Luster AD, Van Rooijen N, Voehringer D, Locksley RM (2007) Chitin induces accumulation in tissue of innate immune cells associated with allergy. Nature 447:92-96

Rehli M, Krause SW, Andreesen R (1997) Molecular characterization of the gene for human cartilage gp-39 (CHI3L1), a member of the chitinase protein family and marker for late stages of macrophage differentiation. Genomics 43:221-225

Ren B, Zhang N, Yang J, Ding H (2008) Nitric oxide-induced bacteriostasis and modification of iron-sulphur proteins in Escherichia coli. Mol Microbiol 70:953-964

Ricchetti GA, Williams LM, Foxwell BM (2004) Heme oxygenase 1 expression induced by IL-10 requires STAT-3 and phosphoinositol3 kinase and is inhibited by lipopolysaccharide. J Leukoc Biol 76:719-726

Ridnour LA, Thomas DD, Mancardi D, Espey MG, Miranda KM, Paolocci N, Feelisch M, Fukuto J, Wink DA (2004) The chemistry of nitrosative stress induced by nitric oxide and reactive nitrogen oxide species. Putting perspective on stressful biological situations. Biol Chem 385:1-10

Ronaldson PT, Demarco KM, Sanchez-Covarrubias L, Solinsky CM, Davis TP (2009) Transforming growth factor-beta signaling alters substrate permeability and tight junction protein expression at the blood-brain barrier during inflammatory pain. J Cereb Blood Flow Metab 29:1084-1098

Rubartelli A, Lotze MT (2007) Inside, outside, upside down: damageassociated molecular-pattern molecules (DAMPs) and redox. Trends Immunol 28:429-436

Salimuddin NA, Gotoh T, Isobe H, Mori M (1999) Regulation of the genes for arginase isoforms and related enzymes in mouse macrophages by lipopolysaccharide. Am J Physiol 277:E110-E117

Sandler NG, Mentink-Kane MM, Cheever AW, Wynn TA (2003) Global gene expression profiles during acute pathogen-induced pulmonary inflammation reveal divergent roles for Th1 and Th2 responses in tissue repair. J Immunol 171:3655-3667

Schaer DJ, Boretti FS, Schoedon G, Schaffner A (2002) Induction of the CD163-dependent haemoglobin uptake by macrophages as a novel anti-inflammatory action of glucocorticoids. Br J Haematol 119:239-243

Schilling M, Besselmann M, Muller M, Strecker JK, Ringelstein EB, Kiefer R (2005) Predominant phagocytic activity of resident microglia over hematogenous macrophages following transient focal cerebral ischemia: an investigation using green fluorescent protein transgenic bone marrow chimeric mice. Exp Neurol 196:290-297

Schwartz M, London A, Shechter R (2009) Boosting T-cell immunity as a therapeutic approach for neurodegenerative conditions: the role of innate immunity. Neuroscience 158:1133-1142

Scotton CJ, Martinez FO, Smelt MJ, Sironi M, Locati M, Mantovani A, Sozzani S (2005) Transcriptional profiling reveals complex regulation of the monocyte IL-1 beta system by IL-13. J Immunol 174:834-845
Serhan CN, Levy B (2003) Novel pathways and endogenous mediators in anti-inflammation and resolution. Chem Immunol Allergy 83:115-145

Shah VB, Huang Y, Keshwara R, Ozment-Skelton T, Williams DL, Keshvara L (2008) Beta-glucan activates microglia without inducing cytokine production in Dectin-1-dependent manner. $\mathrm{J}$ Immunol 180:2777-2785

Shimohama S, Tanino H, Kawakami N, Okamura N, Kodama H, Yamaguchi T, Hayakawa T, Nunomura A, Chiba S, Perry G, Smith MA, Fujimoto S (2000) Activation of NADPH oxidase in Alzheimer's disease brains. Biochem Biophys Res Commun 273:5-9

Shin WH, Lee DY, Park KW, Kim SU, Yang MS, Joe EH, Jin BK (2004) Microglia expressing interleukin-13 undergo cell death and contribute to neuronal survival in vivo. Glia 46:142-152

Snell JC, Chernyshev O, Gilbert DL, Colton CA (1997) Polyribonucleotides induce nitric oxide production by human monocytederived macrophages. J Leukoc Biol 62:369-373

Sotgiu S, Musumeci S, Marconi S, Gini B, Bonetti B (2008) Different content of chitin-like polysaccharides in multiple sclerosis and Alzheimer's disease brains. J Neuroimmunol 197:70-73

Soulet D, Rivest S (2008) Bone-marrow-derived microglia: myth or reality? Curr Opin Pharmacol 8:508-518

Sterka D Jr, Marriott I (2006) Characterization of nucleotide-binding oligomerization domain (NOD) protein expression in primary murine microglia. J Neuroimmunol 179:65-75

Stoeck K, Bodemer M, Ciesielczyk B, Meissner B, Bartl M, Heinemann U, Zerr I (2005) Interleukin 4 and interleukin 10 levels are elevated in the cerebrospinal fluid of patients with Creutzfeldt-Jakob disease. Arch Neurol 62:1591-1594

Streit WJ, Kincaid-Colton CA (1995) The brain's immune system. Sci Am 273(54-55):58-61

Stutz AM, Pickart LA, Trifilieff A, Baumruker T, Prieschl-Strassmayr E, Woisetschlager M (2003) The Th2 cell cytokines IL-4 and IL-13 regulate found in inflammatory zone $1 /$ resistin-like molecule alpha gene expression by a STAT6 and CCAAT/enhancer-binding proteindependent mechanism. J Immunol 170:1789-1796

Suzuki Y, Claflin J, Wang X, Lengi A, Kikuchi T (2005) Microglia and macrophages as innate producers of interferon-gamma in the brain following infection with Toxoplasma gondii. Int J Parasitol 35:83-90

Szczepanik AM, Funes S, Petko W, Ringheim GE (2001) IL-4, IL-10 and IL-13 modulate A beta(1-42)-induced cytokine and chemokine production in primary murine microglia and a human monocyte cell line. J Neuroimmunol 113:49-62

Takahashi K, Rochford CD, Neumann H (2005) Clearance of apoptotic neurons without inflammation by microglial triggering receptor expressed on myeloid cells-2. J Exp Med 201:647-657

Taketomi T, Hara A, Kasama T (1984) Cerebral and visceral organ gangliosides and related glycolipids in gm1-gangliosidosis type 1, type 2 and chronic type. Adv Exp Med Biol 174:419-429

Tan J, Town T, Mori T, Wu Y, Saxe M, Crawford F, Mullan M (2000) CD45 opposes beta-amyloid peptide-induced microglial activation via inhibition of p44/42 mitogen-activated protein kinase. J Neurosci 20:7587-7594

Taylor KR, Gallo RL (2006) Glycosaminoglycans and their proteoglycans: host-associated molecular patterns for initiation and modulation of inflammation. FASEB J 20:9-22

Taylor PR, Gordon S, Martinez-Pomares L (2005a) The mannose receptor: linking homeostasis and immunity through sugar recognition. Trends Immunol 26:104-110

Taylor PR, Martinez-Pomares L, Stacey M, Lin HH, Brown GD, Gordon S (2005b) Macrophage receptors and immune recognition. Annu Rev Immunol 23:901-944

Taylor PR, Reid DM, Heinsbroek SE, Brown GD, Gordon S, Wong SY (2005c) Dectin-2 is predominantly myeloid restricted and exhibits unique activation-dependent expression on maturing 
inflammatory monocytes elicited in vivo. Eur $\mathrm{J}$ Immunol $35: 2163-2174$

Thomas T, Thomas TJ (2001) Polyamines in cell growth and cell death: molecular mechanisms and therapeutic applications. Cell Mol Life Sci 58:244-258

Thomas DD, Ridnour LA, Isenberg JS, Flores-Santana W, Switzer $\mathrm{CH}$, Donzelli S, Hussain P, Vecoli C, Paolocci N, Ambs S, Colton CA, Harris CC, Roberts DD, Wink DA (2008) The chemical biology of nitric oxide: implications in cellular signaling. Free Radic Biol Med 45:18-31

Tiemessen MM, Jagger AL, Evans HG, van Herwijnen MJ, John S, Taams LS (2007) CD4 + CD25 + Foxp3+ regulatory T cells induce alternative activation of human monocytes/macrophages. Proc Natl Acad Sci U S A 104:19446-19451

Tili E, Michaille JJ, Cimino A, Costinean S, Dumitru CD, Adair B, Fabbri M, Alder H, Liu CG, Calin GA, Croce CM (2007) Modulation of miR-155 and miR-125b levels following lipopolysaccharide/TNF-alpha stimulation and their possible roles in regulating the response to endotoxin shock. J Immunol 179:5082-5089

Townsend KP, Vendrame M, Ehrhart J, Faza B, Zeng J, Town T, Tan J (2004) CD45 isoform RB as a molecular target to oppose lipopolysaccharide-induced microglial activation in mice. Neurosci Lett 362:26-30

Ulevitch RJ, Mathison JC, da Silva Correia J (2004) Innate immune responses during infection. Vaccine 22(Suppl 1):S25-S30

Underhill DM (2007) Collaboration between the innate immune receptors dectin-1, TLRs, and Nods. Immunol Rev 219:75-87

Underhill DM, Goodridge HS (2007) The many faces of ITAMs. Trends Immunol 28:66-73

Valencia-Sanchez MA, Liu J, Hannon GJ, Parker R (2006) Control of translation and mRNA degradation by miRNAs and siRNAs. Genes Dev 20:515-524

van Lookeren Campagne M, Wiesmann C, Brown EJ (2007) Macrophage complement receptors and pathogen clearance. Cell Microbiol 9:2095-2102

Van Muiswinkel FL, Veerhuis R, Eikelenboom P (1996) Amyloid beta protein primes cultured rat microglial cells for an enhanced phorbol 12-myristate 13-acetate-induced respiratory burst activity. J Neurochem 66:2468-2476

van Rossum D, Hilbert S, Strassenburg S, Hanisch UK, Bruck W (2008) Myelin-phagocytosing macrophages in isolated sciatic and optic nerves reveal a unique reactive phenotype. Glia $56: 271-283$

Villoslada P, Moreno B, Melero I, Pablos JL, Martino G, Uccelli A, Montalban X, Avila J, Rivest S, Acarin L, Appel S, Khoury SJ, McGeer P, Ferrer I, Delgado M, Obeso J, Schwartz M (2008) Immunotherapy for neurological diseases. Clin Immunol 128:294-305

Vincendeau P, Gobert AP, Daulouede S, Moynet D, Mossalayi MD (2003) Arginases in parasitic diseases. Trends Parasitol 19:9-12

Vivien D, Ali C (2006) Transforming growth factor-beta signalling in brain disorders. Cytokine Growth Factor Rev 17:121-128

Wallace HM, Duff PM, Pearson CK, Keir HM (1981) The effect of polyamines of DNA synthesis in vitro. Biochim Biophys Acta 652:354-357

Wallace HM, Fraser AV, Hughes A (2003) A perspective of polyamine metabolism. Biochem J 376:1-14

Wei R, Jonakait GM (1999) Neurotrophins and the anti-inflammatory agents interleukin-4 (IL-4), IL-10, IL-11 and transforming growth factor-beta1 (TGF-beta1) down-regulate $\mathrm{T}$ cell costimulatory molecules B7 and CD40 on cultured rat microglia. J Neuroimmunol 95:8-18

Weinberg JB, Misukonis MA, Shami PJ, Mason SN, Sauls DL, Dittman WA, Wood ER, Smith GK, McDonald B, Bachus KE et al (1995) Human mononuclear phagocyte inducible nitric oxide synthase (iNOS): analysis of iNOS mRNA, iNOS protein, biopterin, and nitric oxide production by blood monocytes and peritoneal macrophages. Blood 86:1184-1195

Weigert A, Tzieply N, von Knethen A, Johann AM, Schmidt H, Geisslinger G, Brune B (2007) Tumor cell apoptosis polarizes macrophages role of sphingosine-1-phosphate. Mol Biol Cell $18: 3810-3819$

Weis N, Weigert A, von Knethen A, Brune B (2009) Heme oxygenase-1 contributes to an alternative macrophage activation profile induced by apoptotic cell supernatants. Mol Biol Cell 20:1280-1288

Weller RO, Subash M, Preston SD, Mazanti I, Carare RO (2008) Perivascular drainage of amyloid-beta peptides from the brain and its failure in cerebral amyloid angiopathy and Alzheimer's disease. Brain Pathol 18:253-266

Wiesinger H (2001) Arginine metabolism and the synthesis of nitric oxide in the nervous system. Prog Neurobiol 64:365-391

Wilcock DM, Lewis MR, Van Nostrand WE, Davis J, Previti ML, Gharkholonarehe N, Vitek MP, Colton CA (2008) Progression of amyloid pathology to Alzheimer's disease pathology in an amyloid precursor protein transgenic mouse model by removal of nitric oxide synthase 2. J Neurosci 28:1537-1545

Wilkinson B, Koenigsknecht-Talboo J, Grommes C, Lee CY, Landreth G (2006) Fibrillar beta-amyloid-stimulated intracellular signaling cascades require Vav for induction of respiratory burst and phagocytosis in monocytes and microglia. J Biol Chem 281: 20842-20850

Williams K (1997) Interactions of polyamines with ion channels. Biochem J 325(Pt 2):289-297

Williams K, Dooley N, Ulvestad E, Becher B, Antel JP (1996) IL-10 production by adult human derived microglial cells. Neurochem Int 29:55-64

Williams LM, Sarma U, Willets K, Smallie T, Brennan F, Foxwell BM (2007) Expression of constitutively active STAT3 can replicate the cytokine-suppressive activity of interleukin-10 in human primary macrophages. J Biol Chem 282:6965-6975

Willment JA, Lin HH, Reid DM, Taylor PR, Williams DL, Wong SY, Gordon S, Brown GD (2003) Dectin-1 expression and function are enhanced on alternatively activated and GM-CSF-treated macrophages and are negatively regulated by IL-10, dexamethasone, and lipopolysaccharide. J Immunol 171:4569-4573

Wink DA, Hanbauer I, Krishna MC, DeGraff W, Gamson J, Mitchell JB (1993) Nitric oxide protects against cellular damage and cytotoxicity from reactive oxygen species. Proc Natl Acad Sci U S A 90:9813-9817

Wink DA, Hanbauer I, Grisham MB, Laval F, Nims RW, Laval J, Cook J, Pacelli R, Liebmann J, Krishna M, Ford PC, Mitchell JB (1996) Chemical biology of nitric oxide: regulation and protective and toxic mechanisms. Curr Top Cell Regul 34:159-187

Wink DA, Miranda KM, Espey MG, Pluta RM, Hewett SJ, Colton C, Vitek M, Feelisch M, Grisham MB (2001) Mechanisms of the antioxidant effects of nitric oxide. Antioxid Redox Signal 3:203-213

Wu Y, Tibrewal N, Birge RB (2006) Phosphatidylserine recognition by phagocytes: a view to a kill. Trends Cell Biol 16:189-197

Wu Z, Tokuda Y, Zhang XW, Nakanishi H (2008) Age-dependent responses of glial cells and leptomeninges during systemic inflammation. Neurobiol Dis 32:543-551

Wynn TA, Thompson RW, Cheever AW, Mentink-Kane MM (2004) Immunopathogenesis of schistosomiasis. Immunol Rev 201:156-167

Xiao YQ, Freire-de-Lima CG, Schiemann WP, Bratton DL, Vandivier RW, Henson PM (2008) Transcriptional and translational regulation of TGF-beta production in response to apoptotic cells. J Immunol 181:3575-3585

Yeramian A, Martin L, Arpa L, Bertran J, Soler C, McLeod C, Modolell M, Palacin M, Lloberas J, Celada A (2006a) Macrophages require distinct arginine catabolism and transport systems for proliferation and for activation. Eur $\mathrm{J}$ Immunol $36: 1516-1526$ 
Yeramian A, Martin L, Serrat N, Arpa L, Soler C, Bertran J, McLeod C, Palacin M, Modolell M, Lloberas J, Celada A (2006b) Arginine transport via cationic amino acid transporter 2 plays a critical regulatory role in classical or alternative activation of macrophages. J Immunol 176:5918-5924

Yu H, Iyer RK, Kern RM, Rodriguez WI, Grody WW, Cederbaum SD (2001) Expression of arginase isozymes in mouse brain. J Neurosci Res 66:406-422

Yu H, Yoo PK, Aguirre CC, Tsoa RW, Kern RM, Grody WW, Cederbaum SD, Iyer RK (2003) Widespread expression of arginase I in mouse tissues. Biochemical and physiological implications. J Histochem Cytochem 51:1151-1160

Zhang G, Ghosh S (2002) Negative regulation of toll-like receptormediated signaling by Tollip. J Biol Chem 277:7059-7065

Zhu J, Guo L, Watson CJ, Hu-Li J, Paul WE (2001) Stat6 is necessary and sufficient for IL-4's role in Th2 differentiation and cell expansion. J Immunol 166:7276-7281

Zocchia C, Spiga G, Rabin SJ, Grekova M, Richert J, Chernyshev O, Colton C, Mocchetti I (1997) Biological activity of interleukin-10 in the central nervous system. Neurochem Int 30:433-439 